\title{
The Healing Shrines of St Phoibammon Evidence of Cult Activity in Coptic Legal Documents
}

\section{English Abstract}

A group of $8^{\text {th }}$ century Coptic child donation documents addressed to the monastery of Apa Phoibammon on the mountain of Jeme in Upper Egypt has been the subject of much discussion. The exclusively male children donated by their parents have always been understood as gifts to the monastery itself, a place where they were, however, not intended to grow up as monks, but to remain as lifelong servants. The reason stated for these donations were miracle healings granted by Apa Phoibammon, the patron saint of that monastery, in his local healing shrine. Such donations of cured former patients are a common feature especially to shrines of healing saints as demonstrated by their frequent descriptions in miracle stories circulating widely in the early Arab period. Juxtaposing phrases used in these Coptic legal texts with those from miracle stories of famous Egyptian healing saints, such as Coluthus, Menas, and Phoibammon himself, can demonstrate the impact hagiography had on daily experience and vice versa. The documentary evidence from Jeme thus forms the missing link between hagiography and reality as it emphasizes the practicalities involved when people were donated as living testimonies of a saint's miraculous healing power. Due to the desire to legalize such donations, a written contract could only have be drawn up with the saint's legal representative, in this case the abbot of the monastery at Jeme, who ran the healing shrine of Apa Phoibammon in which the donated children were to serve.

\section{German Abstract}

Die als Kinderschenkungsurkunden bekannten koptischen Textzeugnisse aus der Gegend um Djeme haben immer wieder zu Diskussionen angeregt, sind dabei jedoch stets als Schenkungen an ein Kloster verstanden worden, an dem die geschenkten Knaben nicht zu Mönchen heranwachsen, sondern ausdrücklich auf Lebenszeit zu Diensten verpflichtet sein sollten, eine Praxis, die zahlreiche Interpretationsschwierigkeiten bereitete. Vor dem Hintergrund hagiographischer Literatur erscheinen diese Zeugnisse der früharabischen Zeit dagegen als natürlicher Bestandteil der Heiligenverehrung und des Heilkults. In gängigen miraculaSammlungen kommt es durch die Hilfe eines Heiligen zu Wunderheilungen, für die sich die so Begnadeten anschließend zu lebenslangem Dienst im Heiligtum verpflichten. Genau dieser Vorgang scheint in den thebanischen Kinderschenkungsurkunden festgehalten worden zu sein, in denen Eltern die Wunderheilungen ihrer Kinder dokumentieren und als Grund der Schenkung anführen. Diese richtet sich faktisch an den Heiligen selbst, dessen Kultstätte jedoch organisatorisch und rechtlich zum gleichnamigen

\footnotetext{
* Research for this article was undertaken as part of the ERC project The Cult of Saints (University of Oxford). A version of it has been presented at the After Rome seminar, hosted at Trinity College Oxford, in June 2015. Translations throughout the article are by the author, unless otherwise indicated.
} 
Kloster gehörte, ein hagiographisch vielfach zelebrierter Vorgang, der im echten Leben nur mit gültiger Rechtsurkunde zweier vertragsfähiger Parteien als unanfechtbar gelten konnte.

\section{The Documentary Evidence}

A group of legal documents from the $8^{\text {th }}$ century concerns donations (

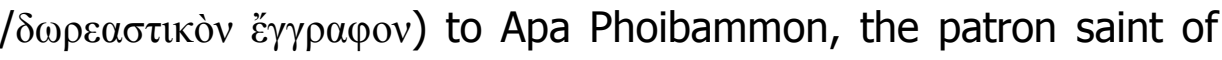
the monastery on the mountain of Jeme in Upper Egypt. These documents attest donations of animals, fields, plants, as well as to self-donations and donations of male children who were handed over by their parents to the "(holy) place" ( Phoibammon as lifelong servants. ${ }^{1}$ The reasons stated for these child donations were miracle healings of the children concerned that had taken place at the saint's sanctuary, which functioned as a local healing shrine. Patients are described as washing with holy water from basins standing next to the altar, a process through which healing was then obtained. The descriptions provided in many of these legal documents offer a glimpse of the family background, providing explanations for the occurrence of an illness for which the patient or its parents blame themselves. In many cases, it is due to an unfulfilled vow or a false oath sworn to the saint, or to general sinful behaviour, that parents felt punished with a fatal illness of their child. These parents then decide to bring their dying child to the sanctuary ( successful, they resolve that their child should remain and live at the saint's holy topos as his servant in return for the healing.

In this article, I will argue that the child donation and self-donation documents addressed to the monastery of Apa Phoibammon on the mountain of Jeme were in fact not dedications to the monastery as such, but to the healing shrine of St Phoibammon which the monastery ran. Consequently, the donated persons were not intended as servants to the monastery, but to the saint and his shrine, serving as living testimonies of the saint's miraculous powers. ${ }^{2}$ Such donations are a common feature especially to shrines of healing saints as demonstrated by their frequent descriptions in miracle stories circulating widely in the early Arab period. When juxtaposing phrases used in these Coptic legal texts with those from miracle stories of famous Egyptian healing saints, such as Kolouthos/Coluthus, Menas, and Phoibammon himself, the potential impact hagiography had on the experience of daily life and vice versa becomes evident.

\footnotetext{
${ }^{1}$ None of the documents discussed here have a secure find-provenance, but their content suggests that they come from the archives of the monastery of Apa Phoibammon on the mountain of Jeme, see details further down.

2 Even though in practice this distinction may have been elided.
} 


\section{The Hagiographical Evidence}

Saint Apa Phoibammon, a young soldier stationed at the Roman army camp at Preht and a recent convert to Christianity, died as a martyr in the city of Assiut (roughly $220 \mathrm{~km}$ north of Jeme) in the early days of the persecution. An edition of a collection of his miracle stories ${ }^{3}$ and the account of his martyrdom ${ }^{4}$ have shed new light on the identity of the saint Phoibammon mentioned in these child donation documents. It becomes now extremely likely that the healing saint at the monastery on the mountain of Jeme is indeed the soldier martyr of Preht rather than one of his two less colourful namesakes, ${ }^{5}$ despite the geographical distances. Though Crum had already pointed out that one of the ostraca he published from the monastery of Apa Phoibammon on the mountain of Jeme listed the feast day of Phoibammon of Preht ( $1^{\text {st }}$ of Pashons), ${ }^{6}$ scholars remained undecided as to the identity of the Phoibammon at Jeme. ${ }^{7}$ Looking at the hagiographical corpus of the soldier martyr Phoibammon of Preht available now, this saint seems to be one with a speciality in detecting unfulfilled oaths and in punishing parents via their children.

In the martyr story of Apa Phoibammon of Preht from the Pierpont Morgan Codex M 582, produced between the years 822 and 913/14, one episode portrays the saint's particular trait as one who punishes parents through the suffering of their children so clearly that there can be little doubt that this is the saint whose powers parents acknowledged and feared even at Jeme. During his trial in the city of Assiut, where he eventually died as a martyr, Phoibammon of Preht, making the sign of the cross had caused so much trouble on the public stage, that the $d u x$ in uncontrollable rage over such disobedience and destruction cursed all Christians collectively. Phoibammon, deeply upset over this, replied in the most intimidating manner possible:

\footnotetext{
${ }^{3}$ From the Pierpont Morgan Codex (M 582), published by Kerry E. Verrone, Mighty Deeds and Miracles by Saint Apa Phoebammon. Edition and Translation of Coptic Manuscript M 582 ff. 21r30r in the Pierpont Morgan Library, Providence, Rhode Island 2002.

${ }^{4}$ Forthcoming edition by Sami Uljas, "The Martyrdom of St Phoibamon of Preht," Pierpont Morgan Codex M 582, ff. 1r-20v", in: Matthias Müller and Sami Uljas (eds.), Of Martyrs and Archangels, vol. I. This is the only complete surviving manuscript of the martyrdom of St Phoibammon which precedes his miracles in the Pierpont Morgan Codex (M 582). I wish to thank Sami Uljas for kindly providing me with his edition prior to publication.

${ }^{5}$ These are Phoibammon, son of John, persecuted by Arianus, with an entry in the Ethiopian synaxarion on 5 Sanê, and Phoibammon, a Roman noble man from Latopolis, martyred north of Antinoopolis and commemorated in the Copto-Arabic synaxarion on 27 Tubi. See the latest discussion by Uljas, "The Martyrdom of St Phoibamon of Preht" (forthcoming).

${ }^{6}$ Walter E. Crum, Coptic Ostraca from the Collections of the Egypt Exploration Fund, the Cairo Museum and Others, London 1902, 41-42 and 75, no. 455; see also Herbert E. Winlock and Walter E. Crum, The Monastery of Epiphanius at Thebes I, New York 1926, 109-110; and Arietta Papaconstantinou, Le culte des saints en Égypte des Byzantins aux Abbassides, Paris 2001, 213.

${ }^{7}$ See Uljas, "The Martyrdom of St Phoibamon of Preht" (forthcoming) for the most recent overview and literature.
} 


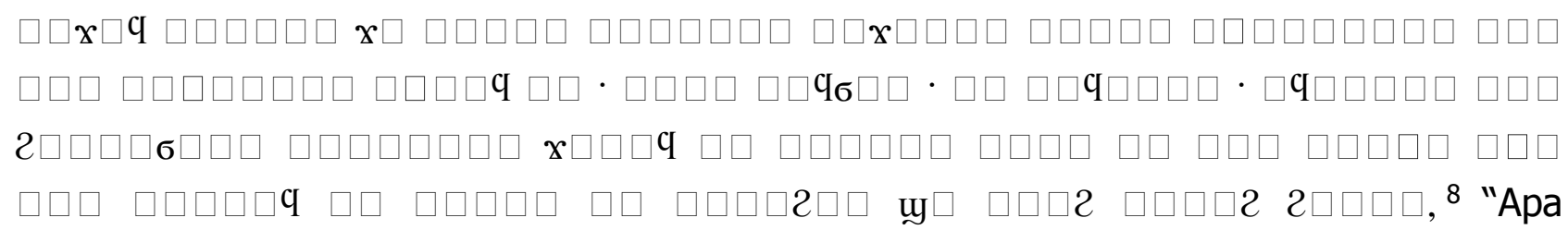
Phoibamon said to the $d u x$. 'Since you have been so daring and have cursed the name of my God, this one whom you do not know - neither his power nor his glory - he shall take revenge on you quickly, so that you recognise that he is the God of heaven and earth, Jesus Christ, this one whose is the glory and the authority eternally. Amen!"' And so fate took its toll and the story continues: $\square 2 \square \square \square \square \square \square \square \square \square \square \square \square \square \square \square \square \square \square \square \mathrm{y} \square \boldsymbol{x} \square \square \square$

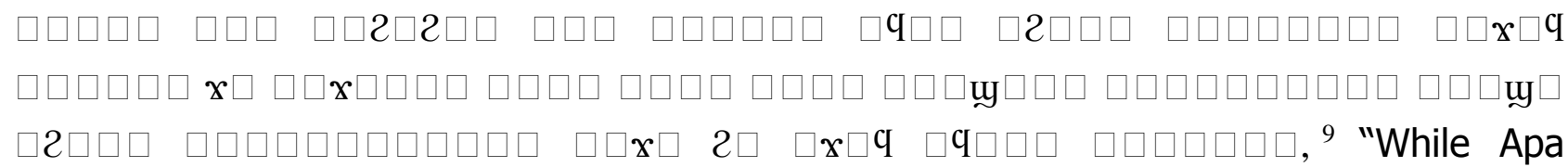
Phoibammon was still speaking with the $d u x$, behold a servant of the comes entered the public bath. He said to the $d u x$ : 'My Lord, listen to me: As your only son was walking into the praetorium, a wall collapsed onto him and he died immediately."' A terrified shudder in the audience is guaranteed.

His miracle stories present Phoibammon as an expert at detecting false vows and unfulfilled oaths. Already the highly inventive introductory story (Fol. 21r I,28-21v II,33) makes this very clear, which sees the emperor Theodosius ${ }^{10}$ arrive at the city of Touho in Egypt. ${ }^{11}$ This is the saint's former home town and his place of burial, which is located between Hermopolis and Kynopolis. The emperor Theodosius arrives on the very day of the feast of saint Phoibammon. Thus, he seizes the opportunity to worship the physical remains of the saint and to implore him to entreat Christ on his behalf to restore him to his former powers in the capital from which he had fled. In return he offers to rebuild the saint's sanctuary far more elaborately and lavishly, befitting Phoibammon's worthiness.

\footnotetext{
8 Uljas, "The Martyrdom of St Phoibamon of Preht", M582 fol. 14r II,34-14v I,12.

9 Uljas, "The Martyrdom of St Phoibamon of Preht", M582 fol. 14v I,12-24.

${ }^{10}$ According to Donald B. Spanel, "Phoibammon of Preht, Martyr," in: The Coptic Encyclopedia, vol. 6., A. S. Atiya (eds.), 1991, 1963-1965, esp. 1964, this refers to the struggle of Theodosius I (379-395) with Magnus Maximus, who seized power in the West in 383. When Theodosius I returned in 388, Magnus Maximus was killed. But Theodosius II (408-450) has also been mentioned as a possible candidate due to his reception by the Coptic church. He was popular with the Coptic Church largely due to his piety and not being Marcian, that is, not responsible for the Council of Chalcedon. This is discussed in a recent article by Edward Watts, "Theodosius II and his legacy in anti-Chalcedonian communal memory", in: Ch. Kelly (ed.), Theodosius II. Rethinking the Roman Empire in Late Antiquity, Cambridge University Press, 2013, 269-284. Also the large basilica at Abu Mina was built by Arcadius and Theodosius II, see Michael Grant, From Rome to Byzantium. The Fifth Century AD, London and New York 1998, 100-101. Needless to say, neither Theodosius I or II ever had to leave Constantinople, let alone visited Egypt.

${ }^{11}$ Known afterwards as Theodosioupolis and later as Taha el-Amida.
} 
The emperor then creates an amulet for himself consisting of wax and garment to protect him on his return journey:

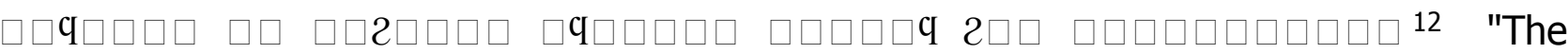
emperor took a piece from the wax (knpíov) which was from his body and (a piece) from the garments and he bound them to himself as a safeguard."

Returning safely to the capital, Theodosius finds himself back in power, with his enemies vanished or defeated. Surprisingly, he does not order the rebuilding of the saint's shrine in Egypt as he had promised. And unsurprisingly, his daughter promptly falls ill, presumably as a result of this delay in fulfilling his promise. The daughter, possessed by a demon, is eventually healed with the help of the amulet which the emperor had created from the saint's wax and cloth (Fol. 21v II,33-22r II,1). Following this miracle healing of his daughter, the emperor snaps into action and orders the rebuilding and enriching of the saint's shrine in Egypt (Fol. 22r II,2-22v I,5).

While about half of the ten miracles recorded in the collection of Pierpont Morgan Codex M 582 take place in or around this shrine in the city of Touho, ${ }^{13}$ the other half mention and promote alternative cult places for Phoibammon. ${ }^{14}$ People living in Hermopolis (Middle Egypt), where this collection of miracles seems to have originated, ${ }^{15}$ seem to have found the journey up north to the city of Touho too long, so the saint himself sets out to promote a local alternative shrine by suggesting a visit to his cult place on the mountain of Thone, proclaiming that his powers work there just as well as they do in Touho, or in Assiut, simply because his name is attached to that locality. This cult

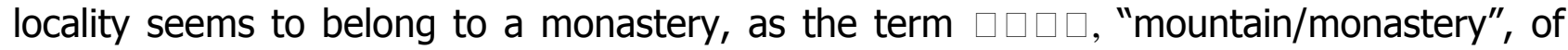
Thone would suggest. Thone itself has been identified with Tuna el-Gebel, ${ }^{16}$ so the shrine

\footnotetext{
12 Verrone, Mighty Deeds and Miracles by Saint Apa Phoebammon, 18, Fol. 21v I,31-35.

13 Miracle two, five, eight, and ten.

${ }^{14}$ Miracle three, four, six and nine.

${ }^{15}$ Compiled by Kolouthos the stylite from Hermopolis. Addressing his audience directly (Verrone, Mighty Deeds, 16, Fol. 21r I,14-15; 48, Fol. 29r II,26-35; and 52, Fol. 30r I,2-8) the compiler identifies himself as Kolouthos, the most humble stylite from Hermopolis, Verrone, Mighty Deeds, 48, Fol. 29r II,34-29v I,2:

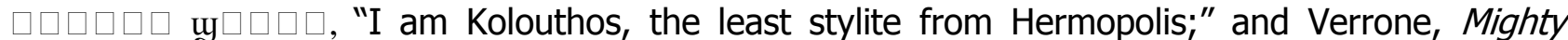
Deeds, 52, Fol. 30r I,9-12:

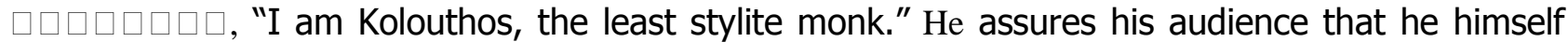
has witnessed these miracles either directly, or has heard of them from other pious and trustworthy men, Verrone, Mighty Deeds, 52, Fol. 30r I,12-23. The fact that the sanctuary of Phoibammon on the mountain of Jeme is not mentioned among the cult localities of saint Phoibammon may have to do with the compiler's local interest, if not the original time of compilation, which was most likely prior to the foundation of the Jeme monastery.

${ }^{16}$ For the identification of Thône as Tuna el-Gebel, see Dieter Kessler, Historische Topographie der Region zwischen Mallawi und Samalut, Wiesbaden 1981, 19, 108.
} 
was presumably located at a monastery near Hermopolis.

In miracle three (Fol. 23r I,21-24v I,6) the saint appears to a pilgrim in despair who wishes to make his yearly offering to the shrine in Touho in accordance with his former vow. His employer, however, does not grant him leave of absence from work and thus he fears divine punishment for neglecting his oath. The saint appears to him in a dream and suggests:

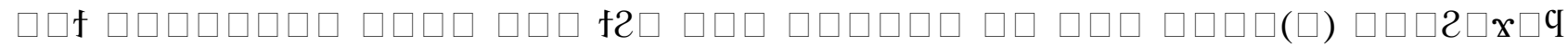
$\square \square \square \square \square \square \square \square$ 2 $\square \square \square \square \square \square \square \square \square \square \square \square \square \square \square \square \square \square \square \square \square \square \square \square 2 \square \square$ I $\square \square \square \square \square \square \square$ 6 $\square \square \square \square$

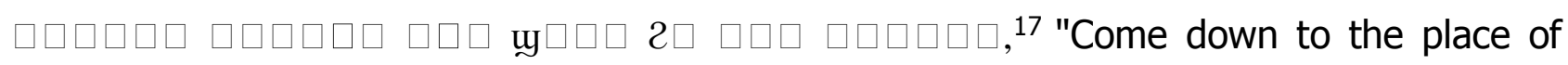
Apa Phoibammon at the mountain of Thone and pray and give your vowed offering, for I am at that place as well. It is my name that is on it. You will proceed just as if you had come to the place where my body is. My powers and the blessing of Jesus Christ are also present at that place."

Similarly in miracle four (Fol. 24v I,7-25r I,32) the saint appears to a former patient who had vowed to bring a container (lakon) of oil to the sanctuary in the city of Touho, if healed. But once healed, he finds it difficult to fulfill this promise as the burial shrine of Phoibammon in Touho is too far away from his home in Hermopolis to carry the oil. Phoibammon appears to the man in distress as a night vision, and instructs him to bring the oil to his sanctuary on the mountain of Thone instead, saying: $\square \square \square \square \square \square \square \square \square 2$

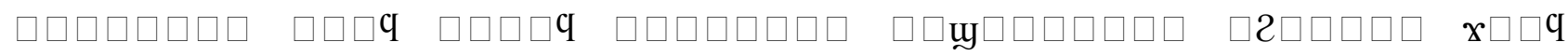

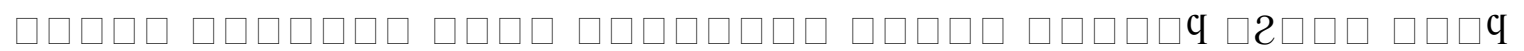

$\square \square \square \square \square \square \square \square 2 \square \mathrm{x} \square \mathrm{C} \square \square \square \square \square \square \square \square \square \square \square \square \square(\square),{ }^{18}$ "The oil container you have promised to donate to my shrine (topos), when you rise in the morning, take it and go to the topos of Apa Phoibamon at Thone and make the offering there, for it is my name that is attached to it. I am Phoibamon."

The man does as instructed and the story continues: $\square \mathrm{Cx} \square \square \square \square \square \square \square \square \square \square \square 2$

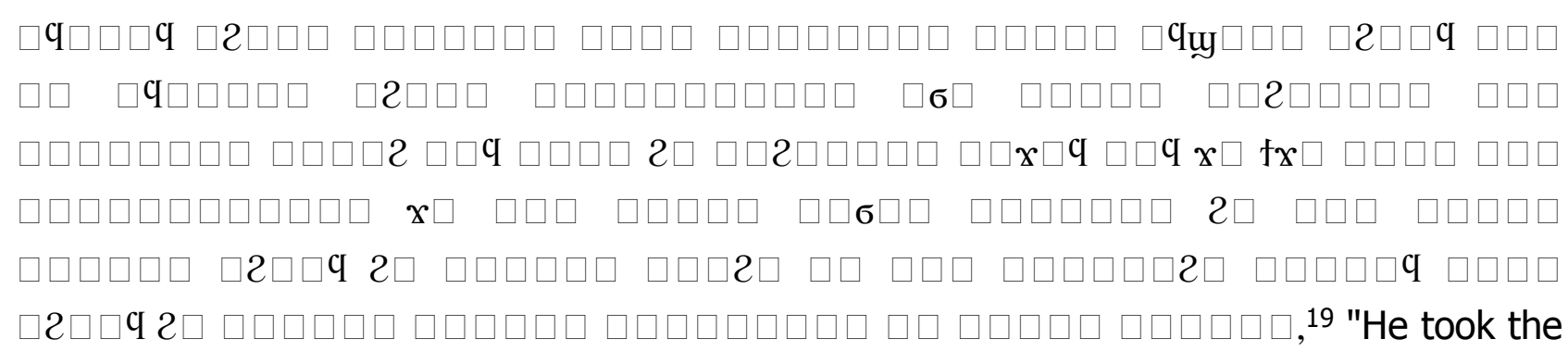
oil container and donated it to the topos of Apa Phoibamon at Thone. He prayed there. And while the man was asleep in the martyr shrine, saint Apa Phoibamon appeared to him

\footnotetext{
${ }^{17}$ Verrone, Mighty Deeds and Miracles by Saint Apa Phoebammon, 26, Fol. 23v I,19-32.

${ }_{18}$ Verrone, Mighty Deeds and Miracles by Saint Apa Phoebammon, 30, Fol. 24v II,20-31.

${ }^{19}$ Verrone, Mighty Deeds and Miracles by Saint Apa Phoebammon, 32, Fol. 25r I,4-25.
} 
in a dream. He said to him, 'I am telling you to make you believe that just as my powers work in the place where my body is, in the city of Touho, and in the place where my blood was shed, in the city of Assiut, they also work now in this place."'

This promotion of cult places shows a well-spun net of shrines for Phoibammon of Preht across the Egyptian landscape. Besides the major shrine in Touho at his burial site, healing miracles also take place in Assiut, at his martyr shrine (martyrion) where the pillar, at which the saint's blood was shed, is located (miracle nine). In addition to the newly promoted monastic shrine at Thone (near Hermoplis), there are other alternative cult places, such as a location close-by across the Nile from Hermopolis, at a place named Pshosh, south of Antinoopolis, where a chapel (eukterion) is said to have impressed a thief with its riches. ${ }^{20}$

Phoibammon's shrines at Touho, Thone, Assiut, and Pshosh function not only as centres for medical healing, but as ultimate places of judgment, where unfulfilled vows are detected and no false oaths go unnoticed. Evil in any form is exposed through the saint, and treated severely and successfully. ${ }^{21}$

As a result of such successful healing, a former patient, a rich man from Assiut, decides to remain in the local shrine as a servant for the rest of his life (Fol. 28r I,3-29r II,25). He had suffered dropsy and had been very ill for eight years. Finally he was brought to the saint's shrine. He had spent much money on doctors, but to no avail, and was now so much swollen that his skin began to break and he was close to death. He was lifted from his bed and carried to the martyr shrine (martyrion) of saint Apa Phoibammon in the city of Assiut. There he was put down on the stone slab by the pillar on which the saint's blood had fallen (Fol. 28r I,27-II,1). While the dropsical man was sleeping in the shrine, Phoibammon appeared to him in a dream and asked him why he was so ill. The dropsical man confessed that in this shrine he had once sworn a false oath in the saint's name. He begged the saint for forgiveness and promised never to swear a false oath again. The saint forgave the man and his sickness disappeared. The man rose completely healed, rejoiced and confessed to the whole crowd what had happened to him. He remained serving in the martyr shrine for the rest of his life:

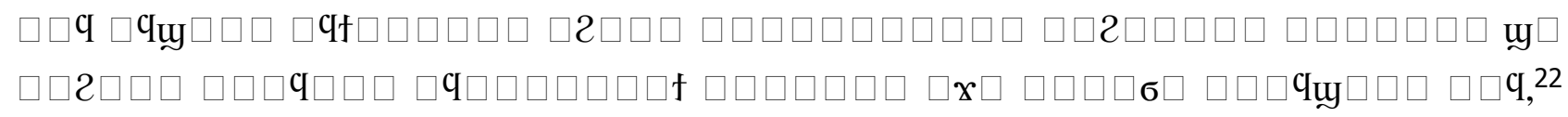

"The man who had obtained healing lived serving in the martyr shrine (martyrion) of saint

\footnotetext{
${ }^{20}$ Miracle six, one desirable item being a bronze double-nozzle lamp.

21 Even in shrines of other saints Phoibammon of Touho acts as the most powerful one, who would not let a false oath go undetected; so in miracle seven when Phoibammon exposes evil doing on the feast day of Apa Hatre in a village called Psahrshbbe.

22 Verrone, Mighty Deeds and Miracles by Saint Apa Phoebammon, 48, Fol. 29r II,14-23.
} 
Phoibammon until the day of his death, thanking God for the healing he had obtained." This combination of a healing miracle following the acknowledgment of a false oath is a common feature also in many donation documents from the Theban area, as we shall see.

\section{Testimonies of a Healing Cult in Action}

Having looked at the hagiographical material, I would now like to turn attention back to the documentary evidence concerning the healing cult of saint Phoibammon on the mountain of Jeme. These documents have come to light mainly through the antiquities market and are available in text editions ${ }^{23}$ and selected translations. ${ }^{24}$

Excavations on the mountain of Jeme at Deir el-Bahari located under the cliffs on the west bank of the Nile, near the Valley of the Kings, were conducted by the Egypt Exploration Fund [the predecessor of the Egypt Exploration Society] in 1894/95 under Eduard Naville. These were directed at the Egyptian middle-kingdom mortuary temple of queen Hatshepsut whose upper levels had been occupied by the monastery of saint Phoibammon. In order to get to the remains of the $18^{\text {th }}$ dynasty Egyptian temple, the Christian habitat had to be destroyed. This was done very successfully, and sadly without any documentation of the process of destruction, which leaves us today with a very large question mark concerning the appearance, size, and structure of this famous monastery known through large numbers of documents.

The still ongoing Polish-Egyptian conservation mission in the area of the temple of Hatshepsut published a volume in 1986 with an attempt to reconstruct the monastery of Apa Phoibammon through its remains and photographs found in the British excavation archives. $^{25}$ This volume also provides a catalogue of the Coptic finds: fragments of wallpainting and ostraca with images, objects of daily use, such as lamps, clothing, mats, and remains of wooden furniture, and numerous papyri assumed to have been taken from the site prior to the British expedition. Many of these papyrus documents are housed in the British Library in London, and to a lesser extent in collections at Cairo and Berlin.

Among the numerous papyri of the $6^{\text {th }}, 7^{\text {th }}$ and $8^{\text {th }}$ century associated with Deir elBahari, there is a self-donation document, P.KRU $104,{ }^{26}$ presumably found at the site of

\footnotetext{
${ }^{23}$ Walter E. Crum and Georg Steindorff, Koptische Rechtsurkunden des achten Jahrhunderts aus Djeme (Theben), Leipzig 1971, 253-323 (P.KRU 78-104, Coptic texts, without translations).

${ }^{24}$ Walter C. Till, Die Koptischen Rechtsurkunden aus Theben, Vienna 1964, 149-188 (German translations of P.KRU 78-104).

${ }_{25}$ Wlodzimierz Godlewski, Le monastère de St Phoibammon, Deir el-Bahari V, Warsaw 1986.

${ }^{26}$ P.KRU 104 refers to Walter E. Crum and Georg Steindorff, Koptische Rechtsurkunden des achten Jahrhunderts aus Djeme (Theben), Leipzig 1971, 321-323.
} 
the monastery and written in 771-772. In it a man named Petronios, son of Georgios, most probably from the town or the region of Jeme, ${ }^{27}$ donates himself as a servant to Apa Phoibammon at the monastery on the mountain of Jeme. Petronios reports that after he had fallen ill and was nearly dying, he received healing only through water brought to him from the holy basin (louter) located in front of the altar in the topos of the saint which was handed out by the steward (oikonomos) of that sanctuary (lines 18-27). The beginning of the document, in which the donor will have identified himself, is lost. Where the surviving part starts, the donor is about to testify that he has his full wits about him, when he is donating himself as a life-long servant to the sanctuary of saint Phoibammon, promising to act in the manner of a servant acquired by money. ${ }^{28}$ (See full text and translation as Text 1 in the Appendix.)

Now then, through the will of God, from today onwards, no one shall be master over my body except for this aforementioned holy monastery of saint Apa Phoibammon, the great martyr, which is located on the holy mountain of Jeme, and I shall be Whoever shall dare and take (legal) action against the holy place (topos) and lay hands on this sacrifice which is my body, this one which I have donated to him, he shall, first of all, not gain anything, but shall be under the true judgment of God."

This is the only self-donation document known or published so far, and thus unique. It clearly testifies to the healing cult of Apa Phoibammon taking place in a sanctuary that was part of a monastery bearing the saint's name. ${ }^{29}$ The donation is made to serve the saint in gratitude and most probably at his shrine; but as that shrine belonged to the monastery, the legal document is addressed to its abbot, who functions as the saint's legally competent deputy.

Self-donations are also a common feature in miracle stories of other saints, such as the famous healing saint Kolouthos/Coluthus, for example. In one of his miracle stories, a former prostitute named Maria donates all her belongings and herself to the saint's shrine

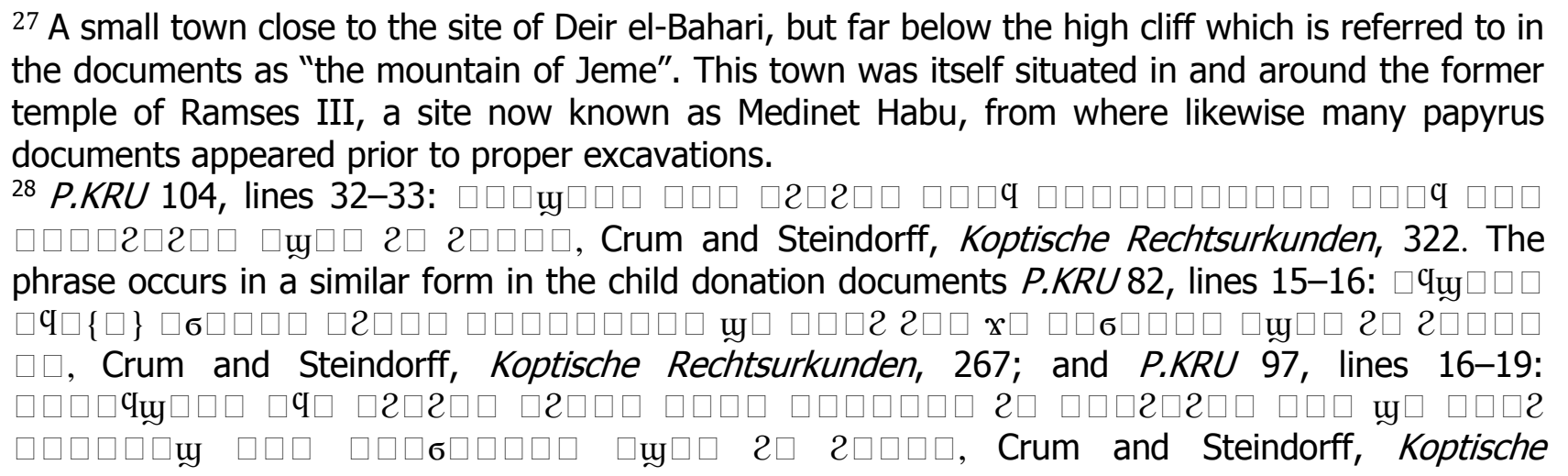
Rechtsurkunden, 306.

${ }^{29}$ Similar to the monastery of Phoibammon at Thone promoted in his miracle stories. 
to serve there for the rest of her life:

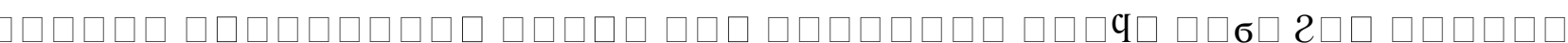

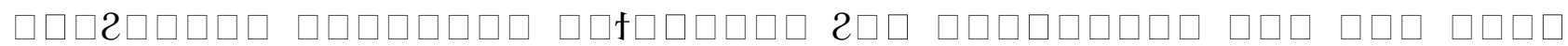
$2 \square \square 2 \square \square \square \square \square \sigma \square x$, "She rose and went to her house. She brought all her possession and her entire supply. She remained in the topos of saint Kolouthos serving through any service and working with her hands." 30

Also many of the miracles from a collection of the well-known Egyptian saint Apa Mena (Pierpont Morgan Codex M 590) show these grateful self-donations. In the sixteenth miracle, for example, a Samaritan woman suffering severe headaches decided to visit the shrine of Apa Mena. On her way, an innkeeper attempts to rape her. She is eventually delivered from both evils, saved from the rapist and healed from her headaches. She becomes a Christian and donates herself to the shrine as a lifelong servant: $\square \square \sigma \square$

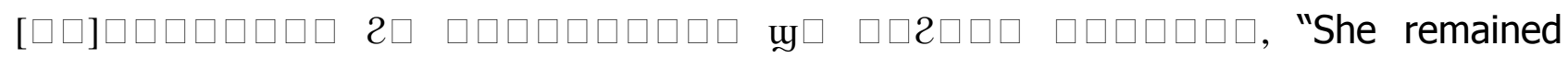
serving in the martyr shrine until the day of her death." ${ }^{131}$ Even the rapist, punished by an illness that petrified his hand, was brought into the same shrine and received healing only after he vowed that he would remain there as a servant for the rest of his life, and so he

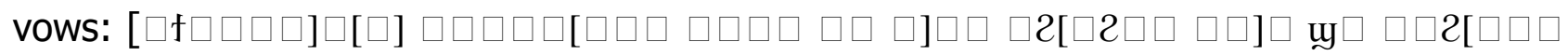

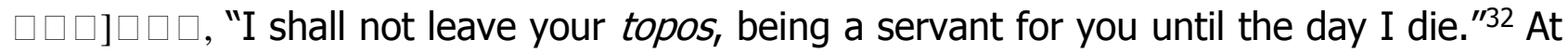

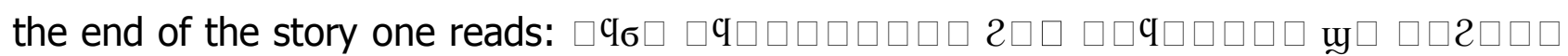
$\square \square \square \mathrm{q} \square \square \square$, "He remained serving in his topos until the day of his death."

Many other items could be donated to the shrine in gratitude, though they usually were in some way connected with the miracle experienced. In miracle three from the collection of miracles of Apa Mena, a rich man from Alexandria intended to donate one of his two silver plates (pinax) to the shrine of Apa Mena, but decided to keep the more exquisite one of the pair for himself. On his way to make the donation, his young servant boy drowned in an attempt to retrieve one of the precious silver plates which had fallen into the water. His master appeals to the saint for help, and the boy-complete with dish-is miraculously saved. Master and servant boy make their way to the shrine of Apa Mena,

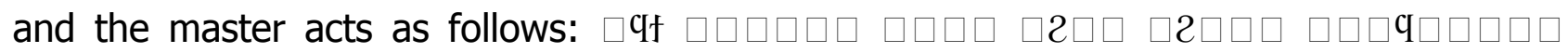

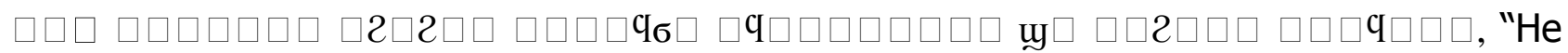

\footnotetext{
${ }^{30}$ Gesa Schenke, Das koptisch hagiographische Dossier des Heiligen Kolluthos - Arzt, Märtyrer und Wunderheiler, eingeleitet, neu ediert, übersetzt und kommentiert, CSCO 650 Subsidia 132, Louvain 2013, 266, Borg. Copt. 109, fol. 244 I,16-II,8.

${ }^{31}$ James Drescher, Apa Mena. A Selection of Coptic Texts Relating to St. Menas, Cairo 1946, 31, M 590, fol. 48r II,14-18.

${ }^{32}$ Drescher, Apa Mena, 32, M 590, fol. 48v I,24-27.

${ }^{33}$ Drescher, Apa Mena, 32, M 590, fol. 48v II,26-29.
} 
donated the two silver plates to his topos and also the young servant boy, so that he would remain serving (there) until the day of his death." 34

Something very similar appears in the so-called child donation documents from the monastery of Apa Phoibammon on the mountain of Jeme. Saint Apa Phoibammon punishes parents for their wrongs, in most cases negligence of former vows, by bringing physical suffering over their children, just as Apa Mena had done in the case of the servant boy, when he punished his master for wishing to keep the finer dish for himself. Of the twenty-six child donation documents ${ }^{35}$ known so far, dating to a fifty-year period between the years 734 and 786, nearly half are entirely preserved. ${ }^{36}$ In these documents parents from Hermonthis, Jeme or the surrounding villages state their desire to donate their son as a lifelong servant to Apa Phoibammon at the monastery on the mountain of Jeme. The explanation provided in these documents is miracle healing bestowed upon these children through the intercession of Apa Phoibammon. ${ }^{37}$ It is explicitly stated that parents proceed with this donation for the salvation of their own soul. In most documents, fathers are donating the child with the consent of its mother. Occasionally, however, this procedure is carried out by mothers acting independently, ${ }^{38}$ as widows, or by simply not mentioning a husband. These documents testify, often in great detail, to the healing cult taking place at the saint's shrine of the monastery dedicated to Apa Phoibammon. Patients remain in the holy place (topos) for a period of time, praying and entreating the saint to grant healing, receiving the Eucharist and washing with holy water.

Formally, these donation documents following a successful healing are drawn up as

${ }^{34}$ Drescher, Apa Mena, 21-22, M 590, fol. 26r II,30- 26v I,5.

35 P.KRU 78-103, Crum and Steindorff, Koptische Rechtsurkunden, 253-320. See also the study of these texts by Anneliese Biedenkopf-Ziehner, Koptische Schenkungsurkunden aus Thebais. Formeln und Topoi der Urkunden, Aussagen der Urkunden, Indices, Göttingen 2001.

${ }^{36}$ P.KRU 79-82 86, 88, 91, 93, 96, 99, 100, Crum and Steindorff, Koptische Rechtsurkunden, 256317.

37 Only two of the complete documents refrain from offering any explanation around an illness for the child donation: P.KRU 99, in which twins are donated, and P.KRU 82 which only mentions an oath given at birth, but no subsequent illness. Seven child donation documents report that a child was pledged to the saint at birth, on the analogy of 1Samuel 1 , but because parents failed to honour this agreement, they were punished with the severe illness of their child. P.KRU 80, 85, 86, $89,96,97$, and 100 belong to this group of documents: child pledged at birth, oath dishonoured, punishment by illness, healing of child, donation. Since also in the self-donation document P.KRU 104 reference is given to Samuel, one might speculate whether Petronios was originally pledged at birth but had failed to be handed over, and therefore fallen fatally ill later in life. A group of nine child donation documents do not mention an oath at birth, P.KRU 78, 79, 81, 84, 88, 91, 93, 98, and 102 , but only a serious childhood illness, the saint entreated for help, the child healed and donated to the saint at the monastery in return, see Crum and Steindorff, Koptische Rechtsurkunden, 253-319.

38 P.KRU 79, 81, 86, 95, see Crum and Steindorff, Koptische Rechtsurkunden, 256-301. 
legal documents, addressed to the managerial body (the dikaion) of the monastery and/or to its current superior. They are written by a professional scribe, read out by a notary, approved by the donor, and signed by several witnesses. They form the final link in a chain of cult events aiming to secure a miracle healing performed in the saint's sanctuary, and are intended to ensure its lasting effect. It is also made explicit in these donation documents that the children (exclusively male) are being given not in order to become monks, but to be servants to the saint at his holy place (topos). The terms used are the

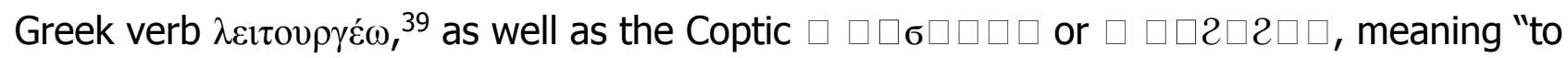

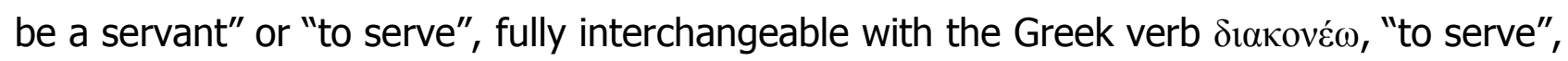
which likewise appears when the boys' future position is stated in some of the hagiographical examples. This service, however, seems first and foremost to have been intended as a religious or cult related one. The term "servant" is here most likely to be understood as a general expression of spiritual rather than as physical belonging, similar to passages in the Septuagint or the New Testament, such as for example in Romans ${ }^{40}$ VI.22,

, "But now that you have become free from sin, you have become servants of God." Similarly in Romans I.1 Paul is the servant of Jesus Christ

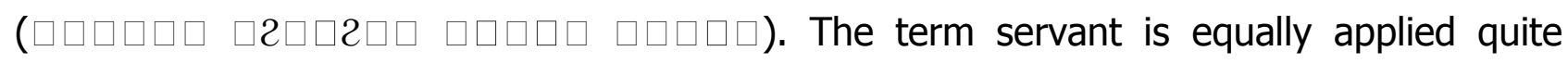
liberally as a common vocative in the Coptic Psalter, Ps 112.1, $\square \square 2 \square \square 2 \square$

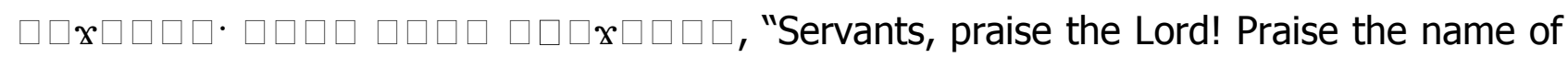
the Lord!" ${ }^{\prime 1}$ The occasional comparison used in the child donation documents to a servant bought for money aims to illustrate the intensity of the spiritual dedication.

In the donation document P.KRU 78 of the $8^{\text {th }}$ century, John, son of Biktor, from Jeme, describes the reason for the donation of his son Biktor:

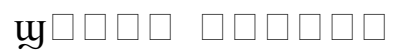

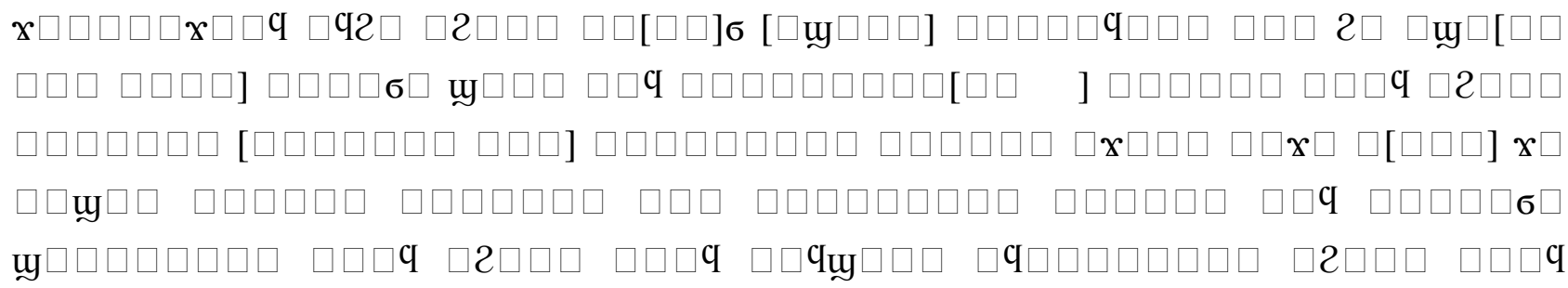

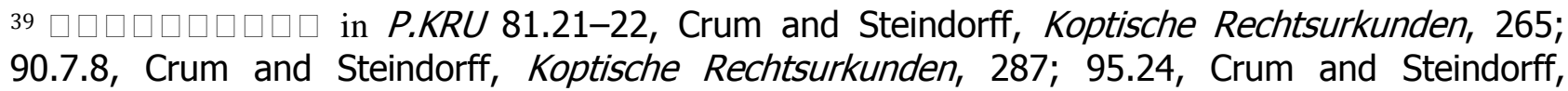
Koptische Rechtsurkunden, 300; 98.7.8.18, Crum and Steindorff, Koptische Rechtsurkunden, 310; and 99.14, Crum and Steindorff, Koptische Rechtsurkunden, 313. P.KRU 87.19 has $x \square \square \square \square \square \square$

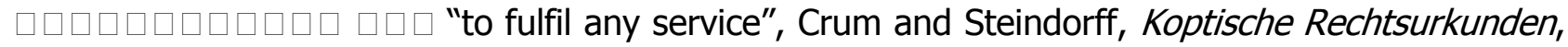
279.

${ }^{40}$ George W. Horner, The Coptic Version of the New Testament in the Southern Dialect, vol. IV, Oxford 1920.

${ }^{41}$ Budge, Ernest A. Wallis, The Earliest Known Coptic Psalter, London 1898, 122. 


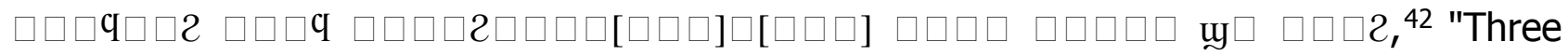
years after I had begotten him, he fell into a severe illness. When he remained ill then with no healing whatsoever taking place for him, I thought [to myself? ...] and I promised him to the topos [of saint Apa] Phoibammon on the mountain of Jeme, saying, 'If God of saint Apa Phoibammon grants him healing, I will donate him to him and he will be contributing to him lifelong (the payment of) one solidus per year eternally."'

In the donation document P.KRU 80 of 12 March 776, Zael, son of Mark, from Hermonthis, donates his son Abraham, who had been pledged to the saint at birth, but not given. Thus a life-threatening illness befalls the boy who is brought into the saint's shrine at the monastery to entreat the saint for a miracle healing. In lines 27-30 of the document it says: $2 \square \square \square \square \square \mathrm{q} \square \square \square \square \square \square \square \square \mathrm{q} \square \square \square \square \square \square \square \square$ ( $\square \square \square \square \square \square \square \square \square$ u $\square \square \square$

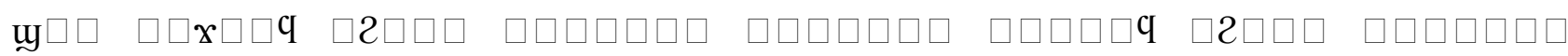

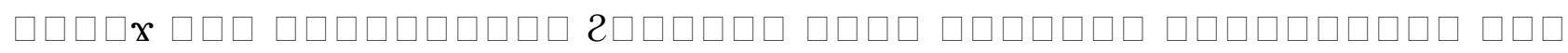

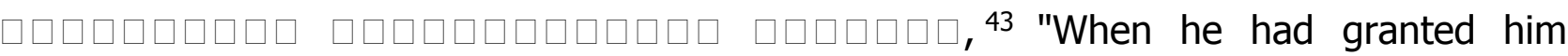
healing, I lifted the small boy and brought him to the holy topos. I donated him to the topos. As a security for the saint, represented through you Sourous, the proestos and oikonomos of the holy monastery, ..." I produced this donation document.

Finally in lines 37-40 the boy's future duties are stated in the following manner:

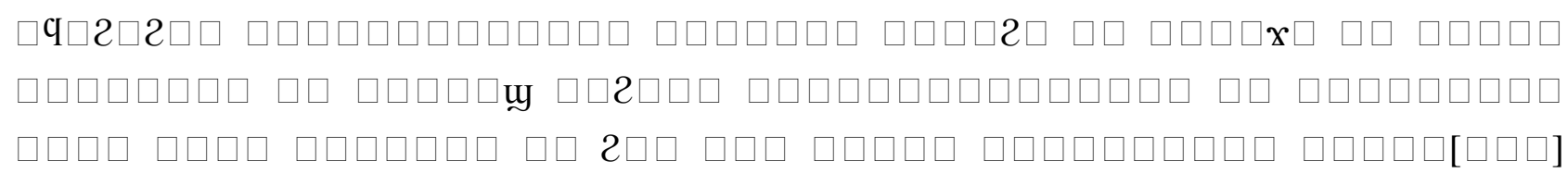
$\square \square \square \square \square \square \square \mathrm{q}, 44$ "... and he shall be a servant at the holy monastery with respect to the sweeping and the sprinkling and the water for the basins and the care for the lamp at the altar and the entire service rendered at the holy topos, as well as everything which the steward (oikonomos) will order him (to do)."

In the complete Coptic child donation document P.KRU 79, a widow named Kalisthene donates her son Merkourios sometime between 765-785. After the child fell ill, his mother implored the saint to cure her son on condition that she would then donate him to serve at the saint's oratory, the place where he received healing. When the boy reached legal age, he agreed to his donation. It is made explicit that the boy is given in order to be a servant at the saint's holy oratory (lines 14-19). Here exceptionally the donation is made not only for the salvation of the donors' souls, i.e. the mother and her deceased husband, but also for the salvation of the donated one, as the boy donated is by now grown up to agree to his donation. He will likewise be responsible for sweeping and sprinkling water

\footnotetext{
42 P.KRU 78, lines 15-25, Crum and Steindorff, Koptische Rechtsurkunden, 254.

43 P.KRU 80, lines 27-30, Crum and Steindorff, Koptische Rechtsurkunden, 261.

44 P.KRU 80, lines 37-40, Crum and Steindorff, Koptische Rechtsurkunden, 262.
} 
and whatever else might be needed in the holy topos (see full text and translation as Text 2 in the Appendix).

Something very similar, but including a broken vow, appears in another such document, P.KRU 86, dated to 29 August 766. A woman named Tachel, daughter of Sophia, from Ape in the district of Hermonthis, is acting together with her sister Elisabeth and donates her son Athanasios. Tachel pledged her child already when he was ill at the age of only seven months; but when he grew up, his mother decided against the donation. As punishment for this sin, God brought a severe illness upon the boy, in the form of a demon. His mother decided to entreat the saint in his sanctuary to grant the boy healing. If he would do so, she would fulfill her original promise and donate the boy as a lifelong servant to the saint's holy topos (see full text and translation as Text 3 in the Appendix).

\section{Lifelong Service in Return for a Saint's Miraculous Intervention}

These child donation documents are drawn up like any lengthy legal document, save for their inclusion of a short paragraph concerning the occurrence of a healing miracle. Looking at these documents in the light of their literary background, it appears that the children concerned were intended not as a donation to the monastery itself, but to the shrine of saint Apa Phoibammon located at that monastery. There they remained and served as living testimony to the saint's miraculous healing powers. The monastery, with its abbot functioning as the saint's legal representative, appears as the addressee of the legal contract, but not as the recipient of the donations as such, even though it would henceforth be held responsible for their well-being and management. Donating their son Pesynthios on 26 May 770, Shenute and his wife Martha, from Jeme in the district of Hermonthis, phrase and summarize this very clearly in P.KRU 84: $\square \square \square 2 \square \square$

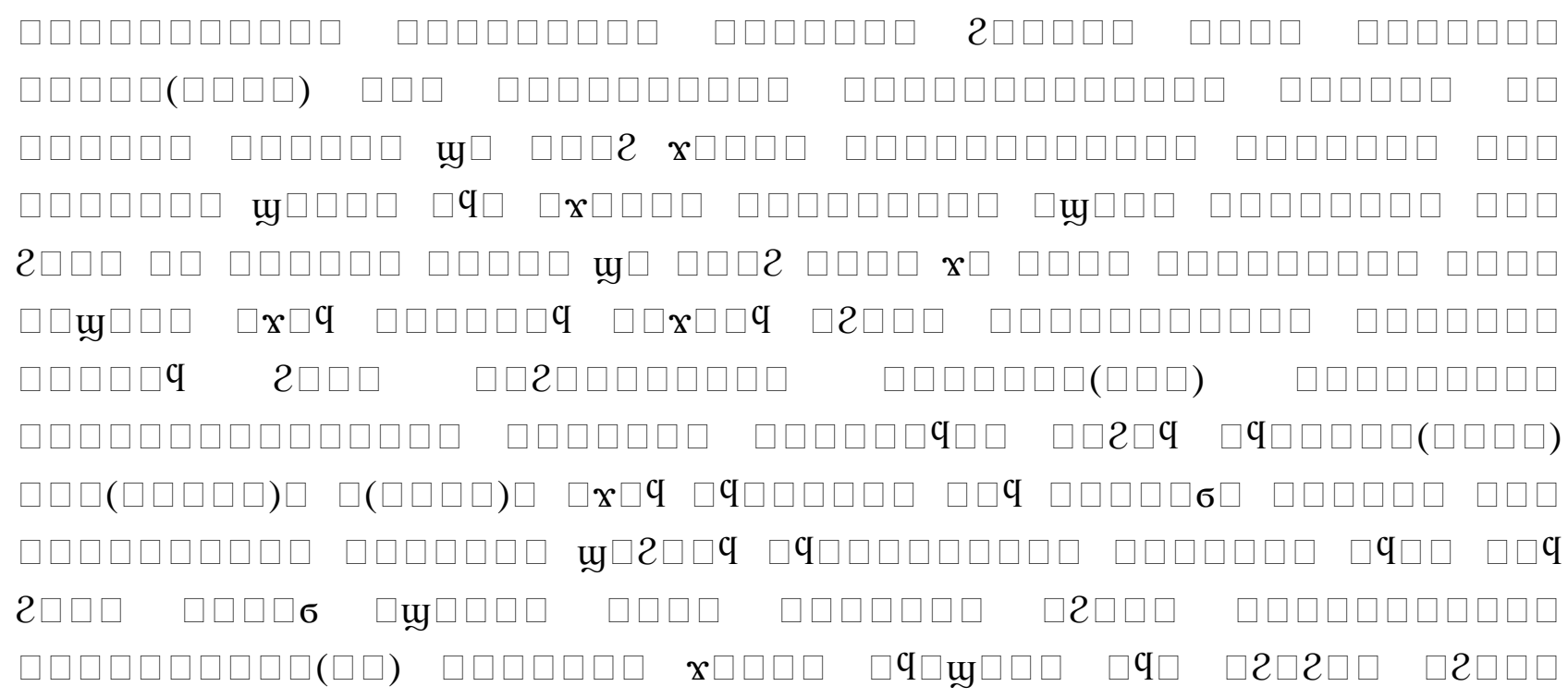




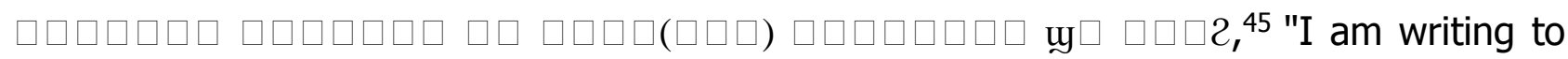
the prize-winning holy martyr, represented through you, Sourous, the deacon and superior of that monastery and through those who come after you eternally, so that the holy martyr Apa Phoibammon shall be master over our beloved son Pesynthios, as concerns me, as well as those that come after me eternally. Because, after God had brought an illness over him, we took him and brought him into the holy martyr shrine. We placed him in front of the sanctuary and we entreated the angel of the holy altar to let his mercy be upon him and to invoke Jesus Christ on his behalf and to let him grant him healing. Afterwards the holy martyr had mercy and entreated God. He was merciful towards him through the great miracle. We proceeded with our donation document as a loving gift, so that he shall be a servant at the holy place and for the lamp there eternally."

The documents from the monastery on the mountain of Jeme were thus not only proof of a legally indisputable donation, but served in turn also as written and living testimonies of the occurrence of a miracle. The collection of these donation documents in itself thus forms a small register of miracles experienced through the power of Apa Phoibammon at the shrine of that monastery, where they were kept as a group in the monastic archives. This is explicitly stated in P.KRU 100, lines 50-52:

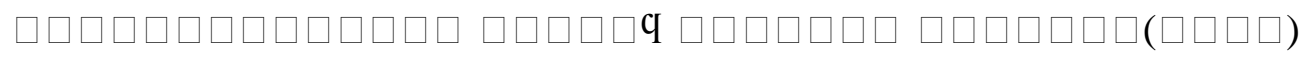

$\square \mathfrak{\mathcal { Q }} \square \square \mathrm{q} 2 \square$

"I proceeded and produced

this donation document. I handed it over to my father, the bishop and oikonomos, so that he would place it in the library of the holy place." These documents were apparently kept closely together, since one document appears written on the back of another, as is the case with P.KRU 80 (12 March 776), which is written on the verso of P.KRU 81 (26 May 771). The five-year gap between these two similar donations strongly suggests that they were recorded and retained as a specific group, since many other donation documents concerning gifts of a different type would have entered the monastic archive within this period.

Since the shrine of Apa Phoibammon formed part of the monastery or was run by it, the legal recipient of any donation to the saint and thus its legal "owner" could therefore only be the monastery. This, however, does not entail that these young servants of Phoibammon were intended or even desired as free labour for the monastery itself, as has been assumed and repeatedly stated. ${ }^{46}$ Nor were they, as recently suggested, disabled or

45 P.KRU 84, lines 14-24, Crum and Steindorff, Koptische Rechtsurkunden, 272-273.

${ }^{46}$ E.g. Heinz-Josef Thissen, "Koptische Kinderschenkungsurkunden. Zur Hierodulie im christlichen Ägypten", Enchoria 14 (1986), 117-128; Arietta Papaconstantinou, "Notes sur les actes de donation d'enfants au monastère thébain de Saint-Phoibammon", The Journal of Juristic Papyrology (JJP) 32 (2002), 83-105; Arietta Papaconstantinou, "Theia oikonomia. Les actes thébains de donation d'enfants ou la gestion monastique de la pénurie", in: Mélanges Gilbert 
illegitimate children whose penniless parents seized the opportunity to relieve themselves of unwanted offspring by fabricating false reports. ${ }^{47}$

The intended place of service for these donated children, who in many cases came with money, ${ }^{48}$ was the saint's shrine, where they seem to have facilitated the healing process by attending to the saint's sanctuary and keeping it clean, presumably along with any adjacent patients' resting quarters. We hear of their responsibility for the (healing) water basin, ${ }^{49}$ for the (oil of the) lamp on the altar, ${ }^{50}$ for the offerings (prosphora) made, ${ }^{51}$ for the sweeping and sprinkling, ${ }^{52}$ and for the handing out bread to visitors, ${ }^{53}$ for all services needed at the holy place, ${ }^{54}$ as well as generally for any necessary matter within or outside of the monastery that they would be asked to do. ${ }^{55}$ The monastery as their legal owner had the right to demand obedience to its rules and regulations $\mathrm{s}^{56}$ and might at times have interpreted their status rather freely according to its needs. After all, just as one could not make a legal contract with a saint, it was likewise not the saint himself, but the organizational structure around his sanctuary-in this case, the monastery-which would

Dagron, Paris 2002, 511-526; Caroline T. Schroeder, "Children and Egyptian Monasteries", in: C. B. Horn und R. R. Phenix (eds.), Children in Late Ancient Christianity. Studien und Texte zu Antike und Christentum 58, Tübingen 2009, 317-338; Ewa Wipszycka, "Resources and Economic Activities of the Egyptian Monastic Communities $\left(4^{\text {th }}-8^{\text {th }}\right.$ century)", The Journal of Juristic Papyrology (JJP) 41 (2011), 159-263, esp. 221-227.

47 Tonio Sebastian Richter, "What's in a story? Cultural narratology and Coptic child donation documents", The Journal of Juristic Papyrology (JJP) 35 (2005), 237-264, esp. 260-261.

${ }^{48}$ E.g. P.KRU 78 and P.KRU 92, Crum and Steindorff, Koptische Rechtsurkunden, 253-256 and 292-294. See the remark by Sophia Schaten, "Koptische Kinderschenkungsurkunden", Bulletin de la Société d'archéologie copte (BSAC) 35 (1996), 129-142, esp. 139. In contrast to others, Schaten, "Koptische Kinderschenkungsurkunden", 136, does point out a religious reason behind these donations and even states, p. 132, that something similar is described in the Life of saint Biktor with reference to Otto van Lemm, "Zu einem Enkomium auf den heiligen Viktor", ZÄS 48 (1910) 81-86. Cf. also Papaconstantinou, "Notes sur les actes de donation d'enfants au monastère thébain de Saint-Phoibammon", 95.

49 P.KRU 80.38, Crum and Steindorff, Koptische Rechtsurkunden, 262; P.KRU 93.32, Crum and Steindorff, Koptische Rechtsurkunden, 296.

50 P.KRU 80.38, Crum and Steindorff, Koptische Rechtsurkunden, 262; P.KRU 93.33, Crum and Steindorff, Koptische Rechtsurkunden, 296; P.KRU 92.14, Crum and Steindorff, Koptische Rechtsurkunden, 292.

51 P.KRU 92.15, Crum and Steindorff, Koptische Rechtsurkunden, 292.

52 P.KRU 80.38, Crum and Steindorff, Koptische Rechtsurkunden, 262; P.KRU 93.32, Crum and Steindorff, Koptische Rechtsurkunden, 296.

53 P.KRU93.33-34, Crum and Steindorff, Koptische Rechtsurkunden, 296.

54 P.KRU 80.39, Crum and Steindorff, Koptische Rechtsurkunden, 262.

55 P.KRU 93.34-37, Crum and Steindorff, Koptische Rechtsurkunden, 296. Similarly also in P.KRU 87.14-23, Crum and Steindorff, Koptische Rechtsurkunden, 279-280; or much shorter in P.KRU 80.39-40, Crum and Steindorff, Koptische Rechtsurkunden, 262.

${ }^{56}$ See for example P.KRU 92, line 13, Crum and Steindorff, Koptische Rechtsurkunden, 292, where the donated boy is to be submissive just as novices or youngsters of all monasteries. 
eventually clothe, feed, and house the "religious gift", so that its overall authority had to be accepted. These practicalities are stated explicitly in P.KRU 87:

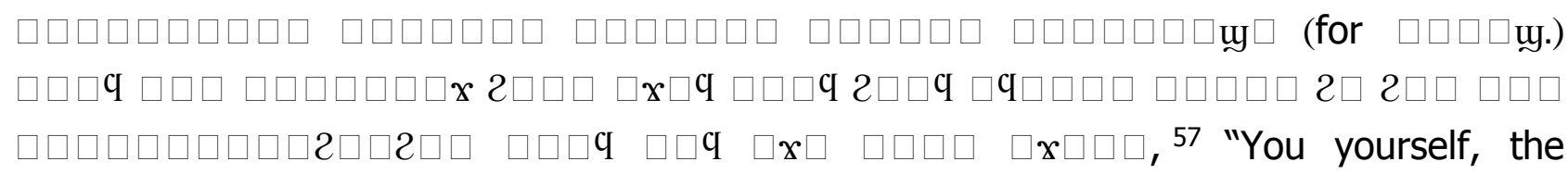
oikonomoi of that holy topos, you shall nourish him and clothe him. He in turn shall obey you in every thing which you will order him to do without any obstruction." Similarly in P.KRU 90, the responsibility of the monastery in return for the service is stated:

$\square \square \square \square \square \square[\square \square \square \mathrm{u}] \quad \square \square \square \mathrm{q} \square \square \square \square \mathrm{q} \square \square 2 \square \square[\square] \square \square \mathrm{x} \square \mathrm{q}$, 58 "And the topos shall [nourish] him and clothe him." It is also the very dominance of the monastery over the healing shrine itself that limits this option for grateful service to men and male children only. Whether alternatives existed in which women and female children had the opportunity to serve as living testimonies of that saint's miraculous powers, remains unknown. In the miracle stories of Apa Mena, for example, we hear that men and women served at the same shrine in life-long gratitude.

It is also reasonable to consider whether or not donations and self-donations narrated in hagiographical texts were naturally understood by their audience to have been accompanied and legalized by a proper donation document. Archives of such documents that record a reason for the donation by summarizing a miraculous experience may have provided the primary material on which later literary corpora of miracles were drawn. In turn, such corpora would then presumably shape the manner in which these religious experiences were expressed and appropriately handled. A set of suitable responses to divine intercession seems to have included the donation of the revived following a neardeath experience, at least in towns and villages of Upper Egypt. An attempt to renegotiate with a saint afterwards caused considerable problems for parents, as described in the Encomion on Viktor the General. Not willing to part with their five-year-old son, whom they had dedicated to the saint's martyr shrine prior to his birth, they offered to pay the value of his service at the shrine, calculating the amount at 40 gold coins. The saint did not accept this exchange and the boy was hit by a stone falling from a house and died. The father realizing the sinful neglect of his earlier vow carries their dead son into the martyr shrine. He begs saint Viktor not to take his anger out on the boy and vows to make himself a servant to the saint in addition to his son. He puts oil from the lamp onto the boy's body. The child awakes and the father donates all his riches and servants and

\footnotetext{
57 P.KRU 87, lines 23-27, Crum and Steindorff, Koptische Rechtsurkunden, 280.

${ }^{58}$ P.KRU 90, lines 8-9, Crum and Steindorff, Koptische Rechtsurkunden, 287.
} 
presumably his son to the martyr shrine and remains himself serving for the rest of his life. ${ }^{59}$

In P.KRU 91, the parents Pesynthe and Tasia leave the decision whether to offer their child or money for the sanctuary to the head of the monastery. After their son Panias received healing through the water at the sanctuary of Phoibammon, they offer to donate Panias himself or the value of his labour. ${ }^{60}$ Sourous, the head of the sanctuary and monastery opts for the boy. However, the possibility for a later payout remains in many instances. In P.KRU 88, the builder Theodoros and his wife Maria donate their son Sonchem to the holy topos of Phoibammon so that he will pay the fruit of his labour to his martyr shrine (martyrion) as a life-long service. ${ }^{61}$ In P.KRU 89, the parents of a boy named Abraham include the following sentence in the deed of donation:

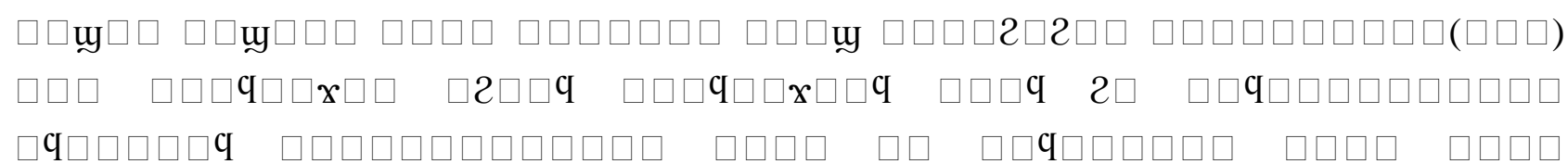

$\square \square \square \square \square \square \square \square$, , 62 "Furthermore, if this particular young boy wishes not to be serving at the monastery, the place where he has been healed, he shall donate to the monastery whatever he will bring forth through the work of his own hands, according to the manner in which it will be arranged with the oikonomos at the time." In P.KRU 80 the same scenario prescribes the wages of the donated boy, earned from living outside the holy place, to be handed over yearly to the oikonomos for the oil of the lamp on the altar. ${ }^{63}$ In P.KRU 81 the vow to donate a boy named Andreas to the saint, if he is healed, leaves it open whether he will serve (leitourgein) physically or pay a regular amount (demosion) for the lamp of the sanctuary. ${ }^{64}$ The desperate vow of the parents Severos and Lia recorded in P.KRU 85 seems to offer only the second option to the saint. If their son Panias is healed, his donation will not involve physical presence at the saint's shrine, but a life-long regular payment intended for its lamp. ${ }^{65}$ In the case of the donated boy Komes in P.KRU 95 , who is to provide all necessary services at the holy topos, even an option for marriage

\footnotetext{
59 The father Alexander, a very rich man had a barren wife. They vowed to donate their child to the shrine, if Viktor would entreat God to let them have an heir, see Ernest A. Wallis Budge, "The Encomium of Celestinus, Archbishop of Rome, on Victor the General", in: Coptic Martyrdoms in the Dialect of Upper Egypt, London 1914, 46-101 (text) and 299-354 (translation), esp. 53-56 (text) and 305-309 (translation).

60 P.KRU91, lines 21-26, Crum and Steindorff, Koptische Rechtsurkunden, 291.

61 P.KRU 88, lines 10-12, Crum and Steindorff, Koptische Rechtsurkunden, 282.

62 P.KRU 89, lines 42-45, Crum and Steindorff, Koptische Rechtsurkunden, 285.

63 P.KRU 80, lines 40-42, Crum and Steindorff, Koptische Rechtsurkunden, 262.

64 P.KRU 81, lines 20-23, Crum and Steindorff, Koptische Rechtsurkunden, 265.

65 P.KRU 85, lines 15-20, Crum and Steindorff, Koptische Rechtsurkunden, 274.
} 
and offspring is given, in which case, however, his children will have to serve (leitourgein) like their father does, ${ }^{66}$ presumably financially.

In preparation for their future cult function, children donated as servants to their healing saint do not appear to be left without parents arranging for their dietary needs, lodgings, pastoral care, and various eventualities concerning their beloved offspring's further development. Such practicalities could only have been arranged by a contract with the governing body of the institution overseeing the healing shrine, in this case the monastery, where the children would be physically accommodated, an aspect of reality largely absent from most literary miracle stories. Likewise absent from hagiographical accounts are mentions of any written documents needed to legalize such thankful donations to the numerous saints and shrines in Egypt. The desire to legalize such donations with a written contract entails the necessity to name the governing institution of the saint's shrine as the legally competent addressee of these gifts and donations, which offers us a glimpse into who ran such successful healing shrines.

\section{Appendix}

\section{Text and Translation of Example Donation Documents}

1. Self-donation document of Petronios, son of Georgios, after receiving healing through the water from the basin located by the altar in the sanctuary of saint Phoibammon; date: 771/772 (P.KRU 104).

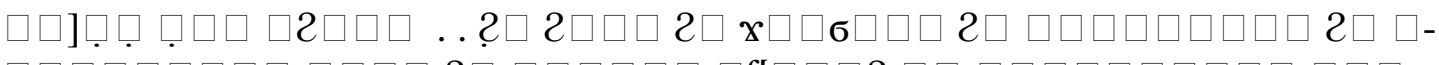

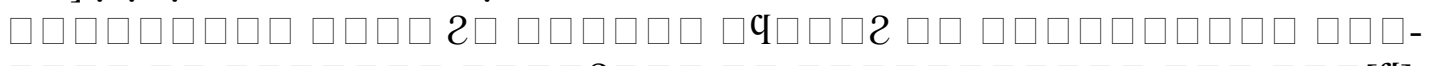

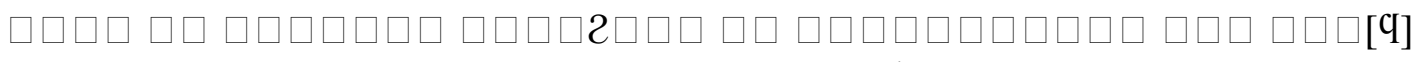

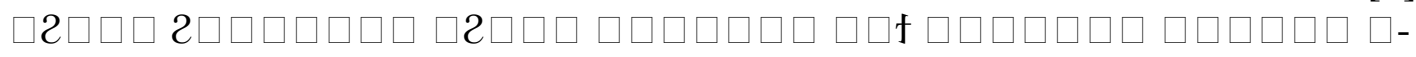

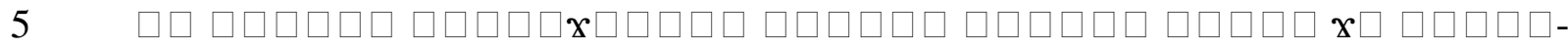

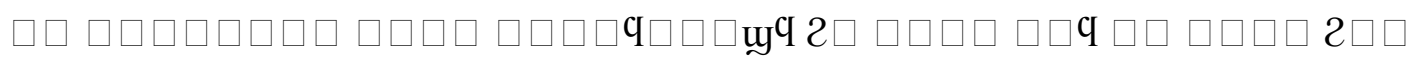
$\square \square \square \square-$

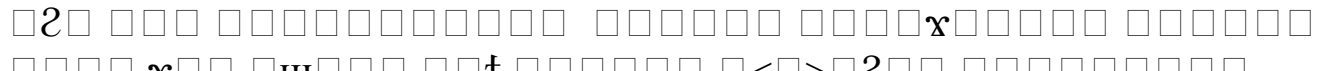

$\square \square \square \square \boldsymbol{x} \square \square \square$ ư $\square \square \square \square \square$ f $\square \square \square \square \square \square \square<\square>\square 2 \square \square \square \square \square \square \square \square \square \square \square$

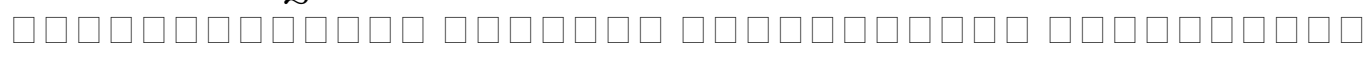

10

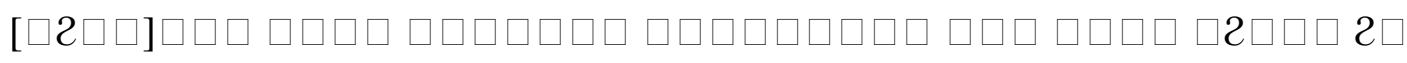

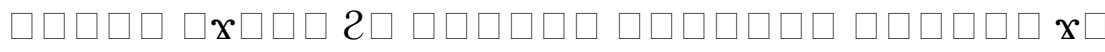

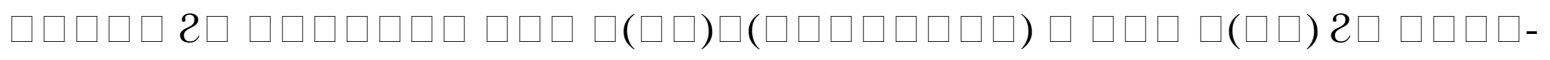

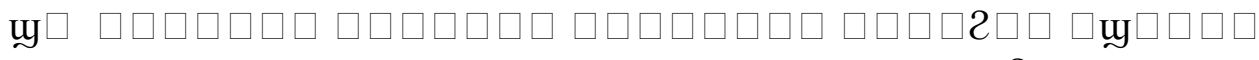

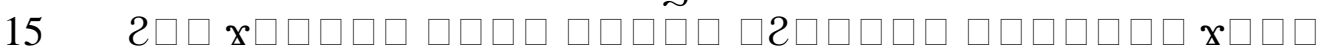

$\square \square \square \square \mathfrak{x} \square \square \square \square \square \square \square \square \square \square \square \square \square 2 \square \square \square \square \square \square \square \square \square \square \square \square \square \square \square \mathrm{q} \square \square \square \square$

66 P.KRU95, lines 22-25, Crum and Steindorff, Koptische Rechtsurkunden, 300. 


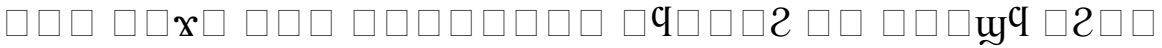

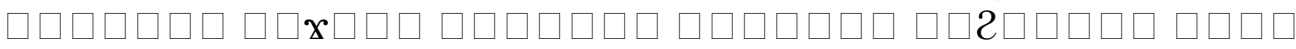

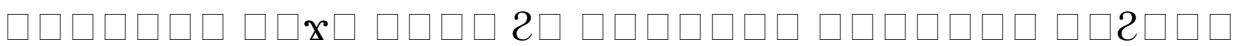

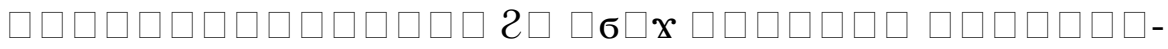

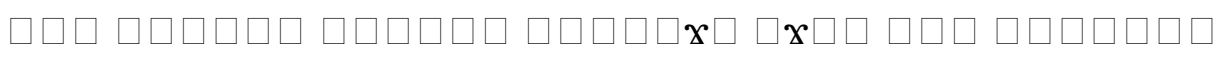

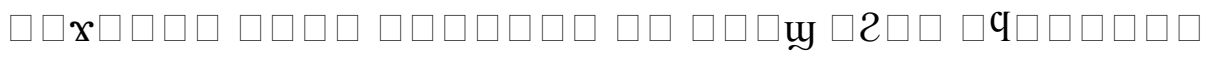

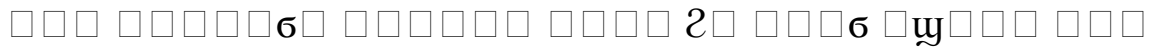

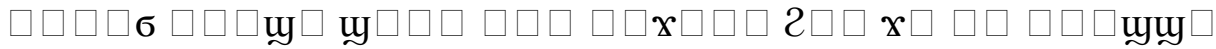

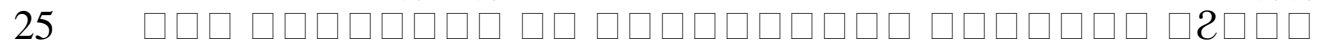
$\square \square \square \mathrm{C} \square \square \square \square \boldsymbol{x} \square \square \square \square \square \square \square \boldsymbol{x} \square \square \square \square 2 \square \square 2 \square \square \square \square \mathrm{q} \square \square \square \square-$

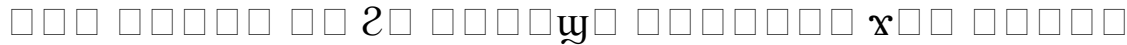

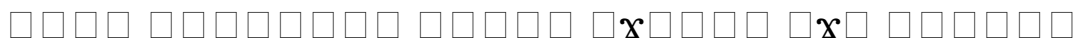

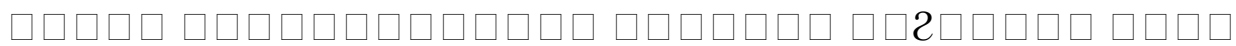

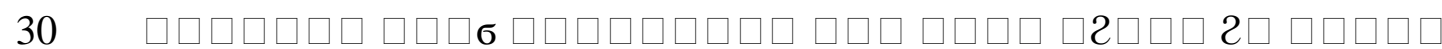

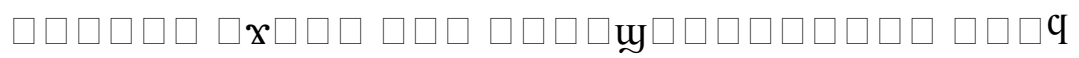
$\mathrm{x} \square \square \mathrm{y} \square \square \square \square \square \square \mathrm{u} \square \square \square \square \square \square \square 2 \square 2 \square \square \square \square \square \mathrm{q} \square \square \square \square \square \square$ $\square \square \square \square \square \square \square \square \mathfrak{q} \square \square \square \square \square \square \square 2 \square 2 \square \square \square \mathrm{u} \square \square 2 \square 2 \square \square \square \square$

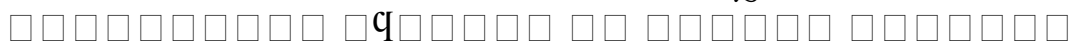

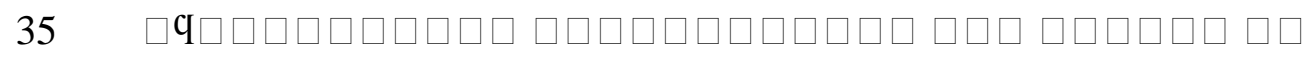

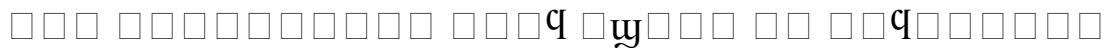

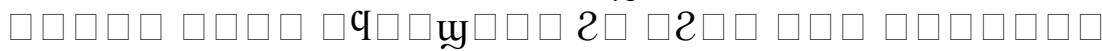

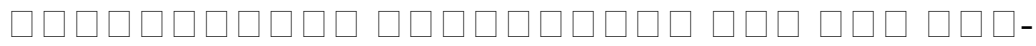

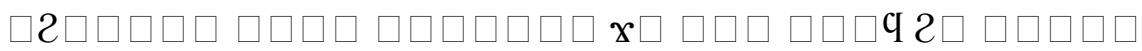
$40 \quad \square \square \square \square \square \square \square \square \square 2 \square 2 \square \square \square \square \square \square \square \square \square \square$ Үug $\square \square \square \square$ I $\square$

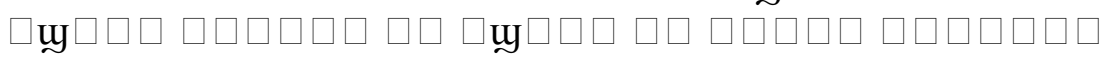

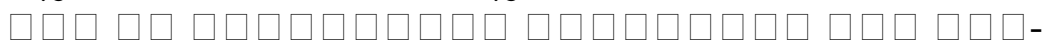

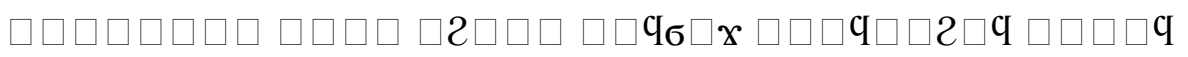
$\square \mathfrak{9} \square \square \square \square \square \boldsymbol{x} \square \square \square \square \square \square \square \square \boldsymbol{x} \square \square \square \square \square \square \square \square \square \square \square \mathfrak{q} \square \square \square \square$

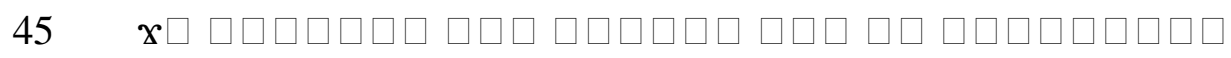

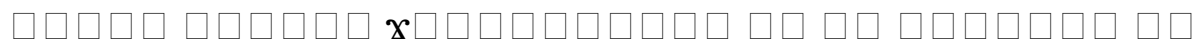

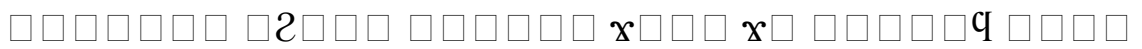

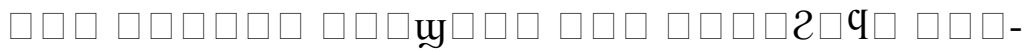

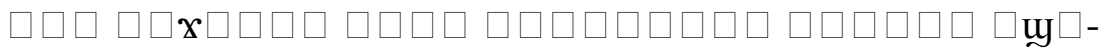

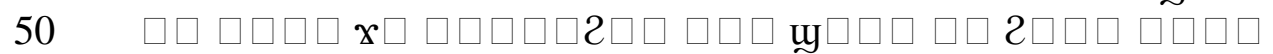

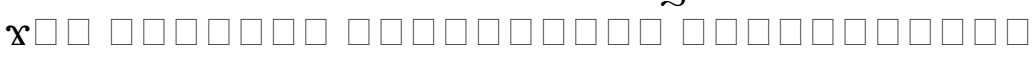

$\square \square \square \mathrm{q} \square 2 \square \square \square \square \square \square \square \square \square \square \mathrm{x} \square \square \square \square \square \square \square \square \square 2 \square \square \square \square \square \square \square \square$

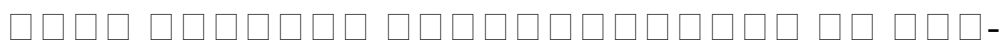

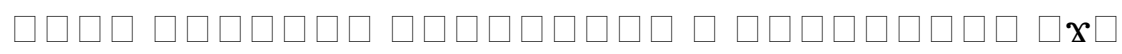

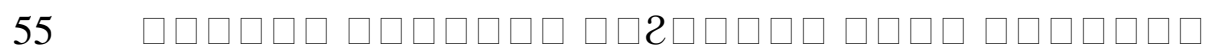
$\square \square \square \square \square \square \square \square 22 \square \square \square \square \square \square \square \boldsymbol{x} \square \square \square \square \square \square \square \square \square \square \square \square \mathbf{6}$

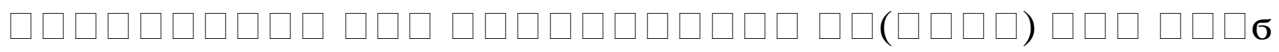

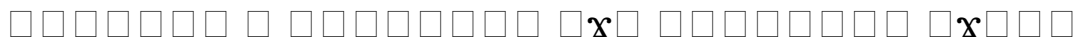

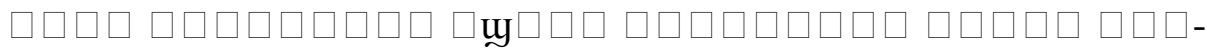

$60 \quad$ G

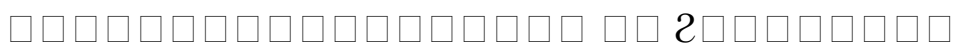

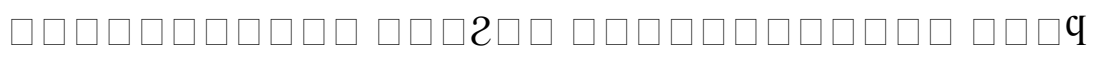

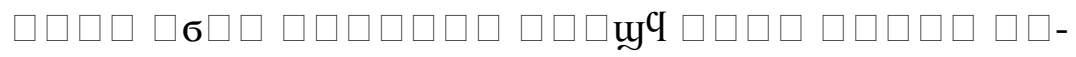

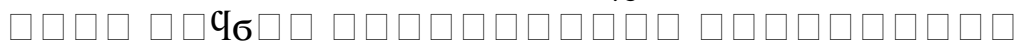


... without any pressure] on me, or fear, force, deceit, or circumvention, but with a sharp mind and unwavering reasoning, a fixed opinion and a guile-lacking conviction, just as towards God, I proceed and obey the laws which the ruling masters have commanded, that it is allowed to let anyone do what he wants with that which is his own. I myself have yielded to the fulfilment of the laws which the masters commanded from the beginning. I went forward writing to the legal body (dikaion) of the holy monastery of the victorious prize bearer, saint Apa Phoibammon, the martyr, this one which is located on the mountain of Jeme in the district of the city of Hermonthis.

In this tenth indiction year, with God, through the will of God, God, the good, the bearer of miraculous judgment, brought a severe illness over me. I dried out and was withering away, so that I was about to die. Faithful people said to me, "Entreat the God of saint Apa Phoibammon, he will have mercy on you." I gained a sharp mind and a deep honest desire, and I sent (someone) to the holy place (topos) of saint Apa Phoibammon. I received water from the holy basin (louter) located by the altar through the holy hands of that steward (oikonomos). It was brought to me and poured over me, and immediately the Lord listened to my crying and my sighing. He granted me healing and I recovered from the severe illness. Great joy came over me and I myself said, "It is befitting and it is just to let me donate my body to him, since health came upon me through his intercession (presbeia)."

Now then, through the will of God, from today onwards, no one shall be master over my body except for this aforementioned holy monastery of saint Apa Phoibammon, the great martyr, which is located on the holy mountain of Jeme, and I shall be serving it and act towards it in the manner of a servant acquired by money.

Whoever shall dare and take (legal) action against the holy place (topos) and lay hands on this sacrifice which is my body, this one which I have donated to him, he shall, first of all, not gain anything, but shall be under the true judgment of God, the Almighty, the true creator (demiourgos); and saint Apa Phoibammon shall take revenge on him at the frightful tribune of God. Furthermore, he shall be a stranger to the Father, the Son, and the Holy Spirit.

I also entreat any authority into whose hands this document will come to let it be put into place as produced, so that God shall bless it, for it is a loving gift to God. And you, my brothers, all know that it is not right to let someone make a gift and let someone else say, "I shall not carry it out." Truly, my brethren, do not act like robbers of promises to the Lord, nor inherit their dwelling places, because, this arrangement was not created through ourselves, but exists and remains since (the time of) Samuel, the prophet, who was given to the temple of the Lord.

We have produced this donation document while the deacon Apa Sourous is the superior (proestos) over the holy place (topos) of Saint Apa Phoibammon located on the mountain of Jeme, and while the great administrator and manager, master Psmo, the 
great official, is financial administrator over the castron Jeme.

I, Petronios, the son of Georgios, have produced (it for) the legal body (dikaion) of the holy monastery. I have asked the notary and trustworthy and truthful witnesses. They bore witness to it according to the power of the laws. The document was read out to us. We have recognised its validity and have agreed, accepted, and confirmed it.

I have executed it through the will of God.

2. Child donation document of the widow Kalisthene who donates her son Merkourios after he was healed through the saint's intercession. When the boy reaches legal age, he agrees to his donation; date: 765-785 (P.KRU79).

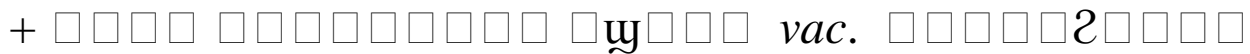

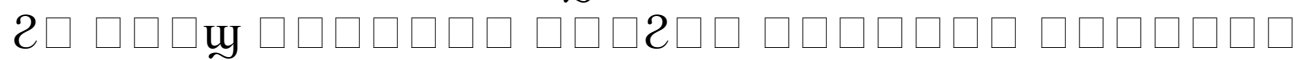

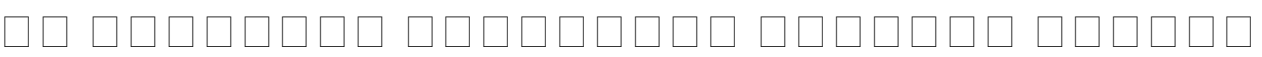

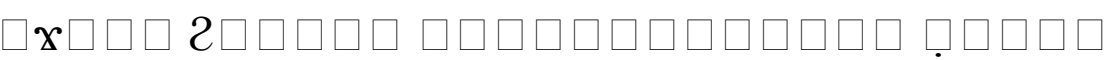

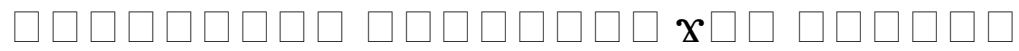

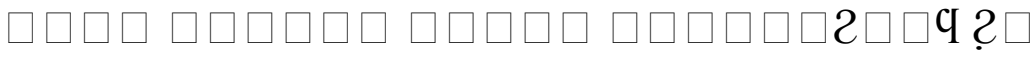

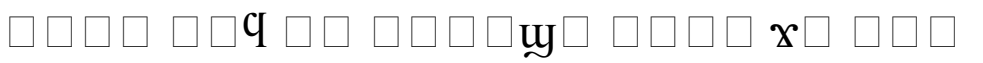

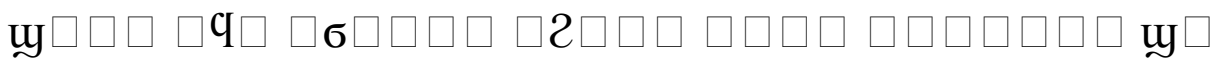

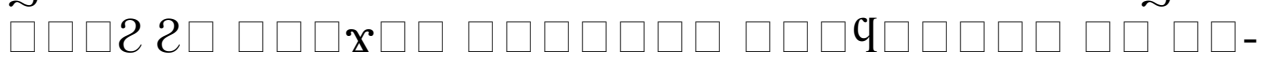

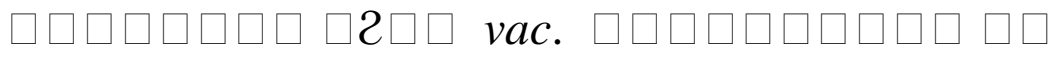




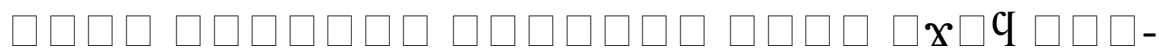

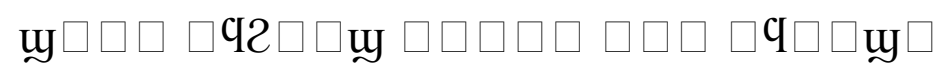

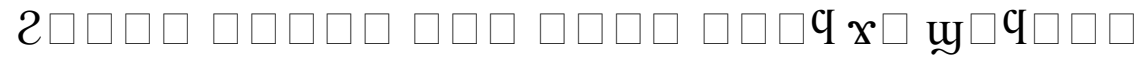

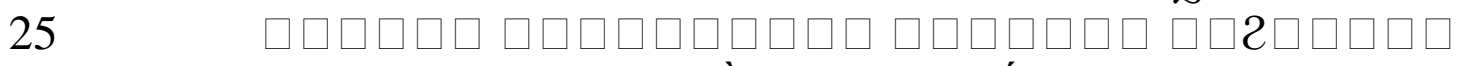

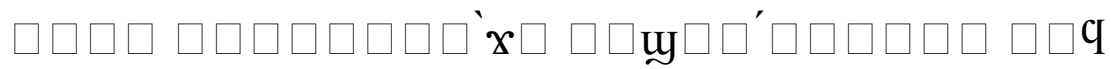

$\square \square \square \square \square \sigma \square$ uู $\square \square-$

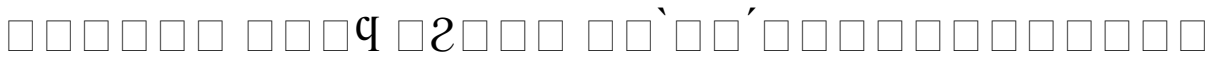

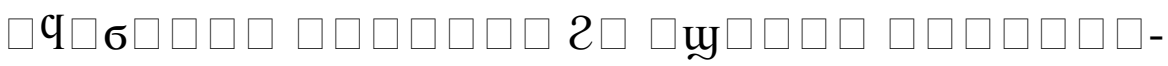

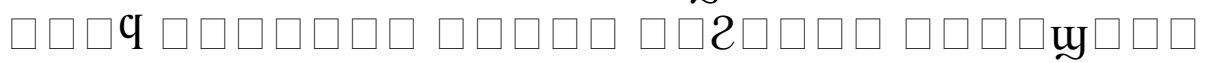

30

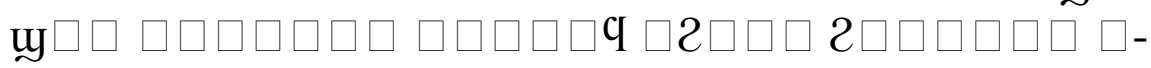

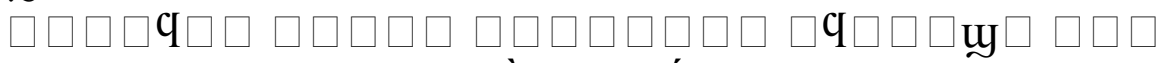

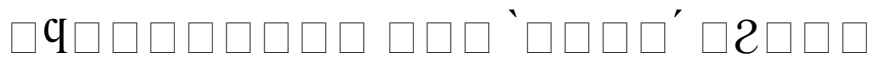

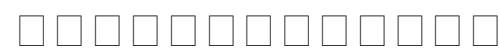

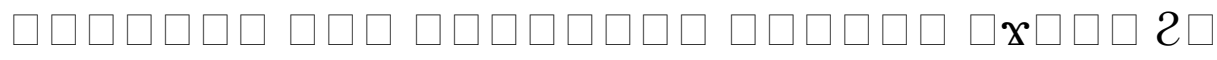

35

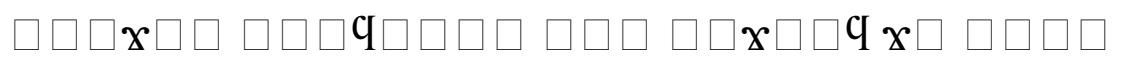

$\square \square \square \square \square \square \square$

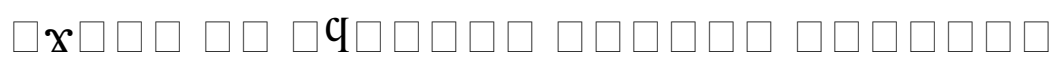

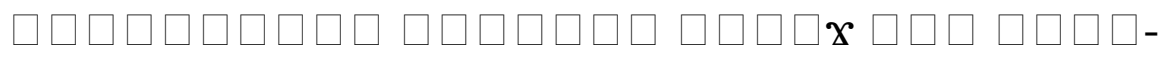

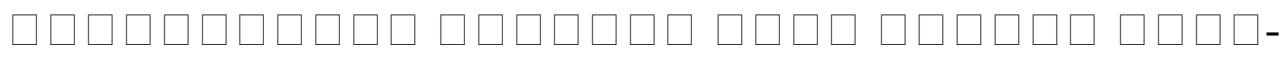

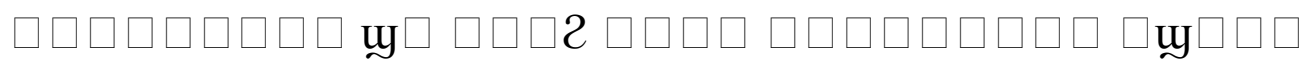
vac. $\quad \square \square \square \square \square \mathrm{u} \square \square \square 2 \square \square \square \square \square \square \square \square \square \square \square \mathrm{ug} \square \square \square \square \square \square-$

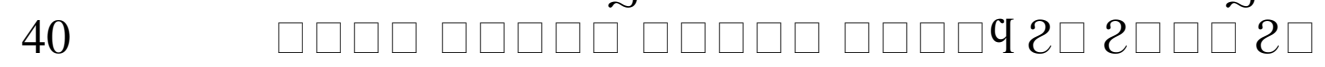

$\boldsymbol{x} \square \square \mathbf{\sigma} \square \square \square$

$\square \square \square \square \square \square \square \square \square$

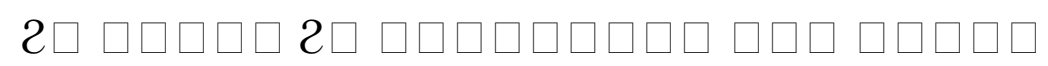

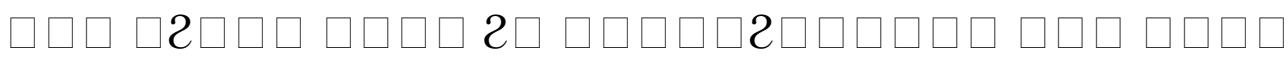
$\square-$

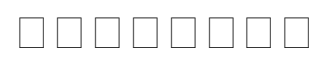

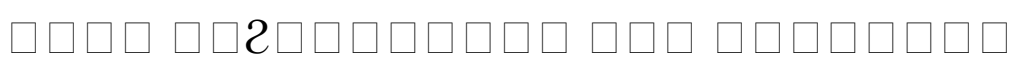

45

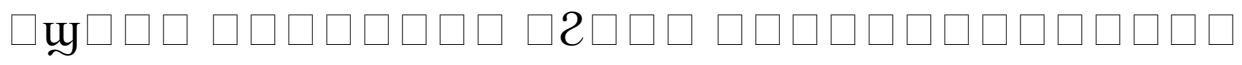

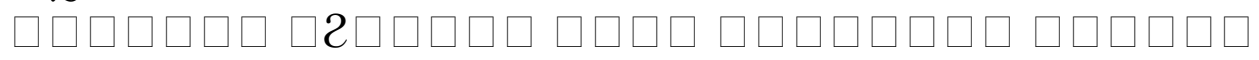
$\square \boldsymbol{x} \square \square \square \square \square \square \square$ Yuy $\square \square \square \square \mathrm{q} \square \square$ ( $\square \square \square \square \square \square \square \mathrm{q}$

$\square \square \square \mathrm{q} \square \square 2 \square \square \square \square \square \mathrm{q} \square \square \square \boldsymbol{x} \square \square \square 2 \square \square \square \square \square \square \square \square \square \square$

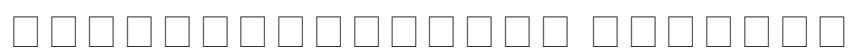

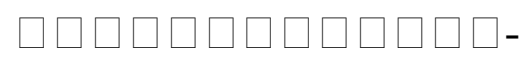

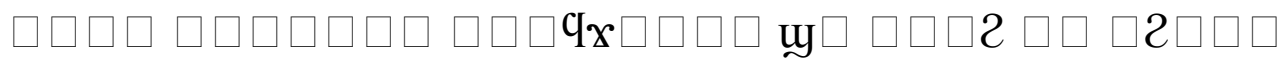

50

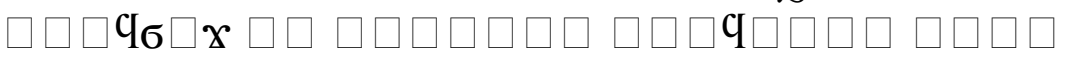

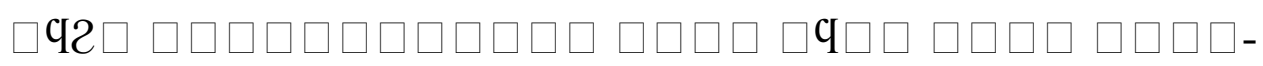

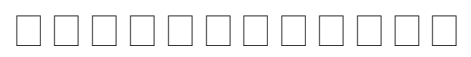

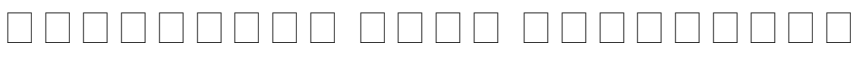

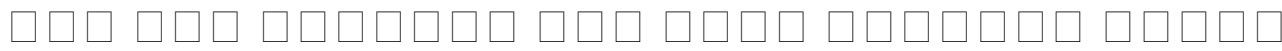




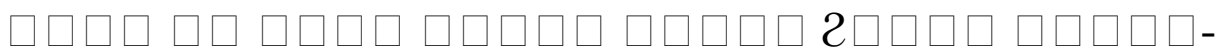

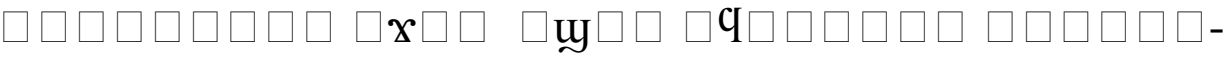

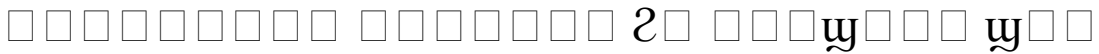

60

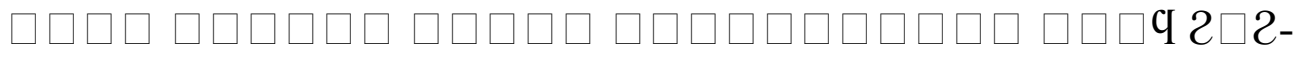

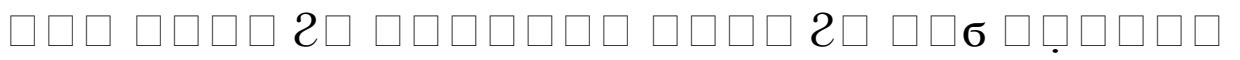

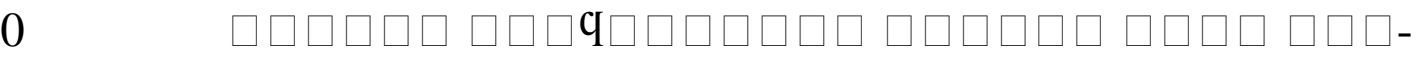

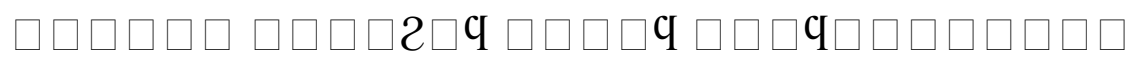

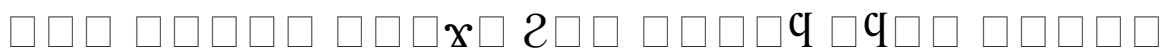

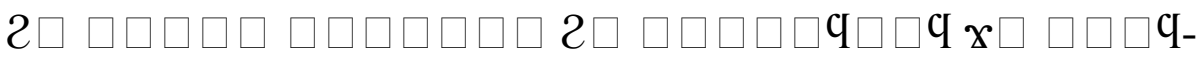

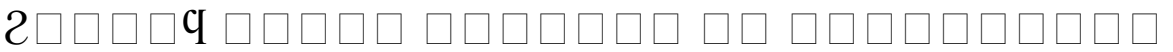

65

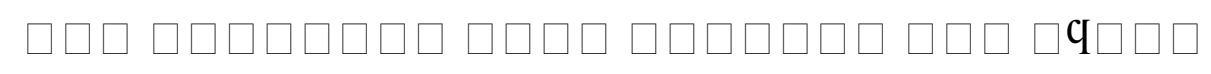

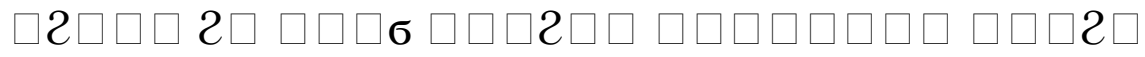

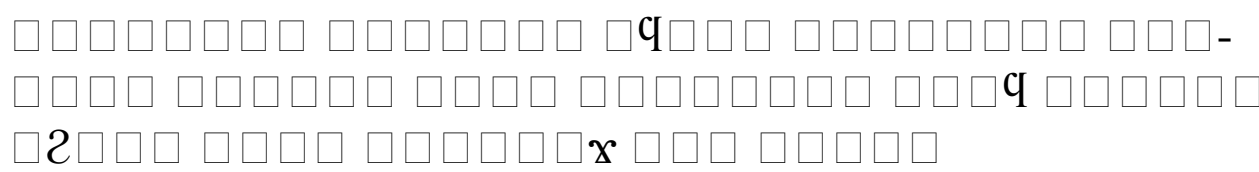

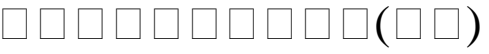

70

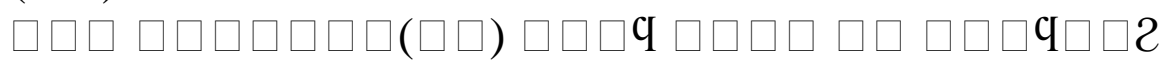

$\square \square \square \square+$

f $\square \square \square \square \square+$

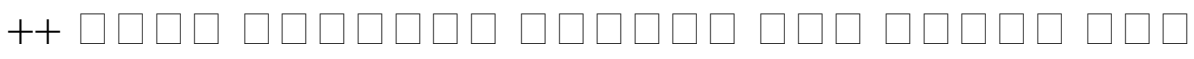

$\mathrm{f} \square \square{ }^{`} \square \square^{\prime}$

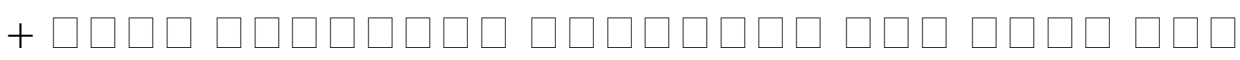

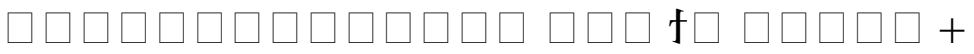

I, Kalisthene, the daughter of $N N$ (space left on the papyrus for the father's name to be added later), resident of Nehbabe in the district of Primide, write to the holy place (topos) of Apa Phoibammon, the holy martyr, on the mountain of Jeme, represented through you, the most pious Apa Sourous, the deacon and superior (proestos) of that holy monastery, and through anyone who will ever be established after him; greetings.

The law of God encourages all of humankind to let them do the good deed, which is pleasing to God, as a benefit to their souls, while no authority hinders anyone to do what he wants with that which is his own.

I considered that I am a sinner, dwelling on earth like all my ancestors, and so I decided and donated my beloved son Merkoure to the holy oratory of saint Apa Phoibammon on the mountain of Jeme, to let him live there as a servant in the holy place eternally for the salvation of my sinful soul and of my blessed husband (space left on the 
papyrus for name).

But I will tell you precisely: When God, the compassionate and merciful, gave the young child to me, afterwards, when the tiny youngster grew up, God, the good one, brought a very difficult and severe illness upon him, so that I gave up on him, since he was to die. Now, we implored the God of saint Apa Phoibammon, "If you grant him healing, I will donate him to your altar and he will serve God in exchange for the kindness you have bestowed upon me." I nurtured this aforementioned young child and brought him up in my knowledge. When he came of age, he wished and agreed to go into the holy monastery of Apa Phoibammon on the mountain of Jeme, for the salvation of his soul. We said that it is a desert place, needing this kind of oath. We were pleased with this kind of good deed.

With respect to the security for this holy monastery, I have proceeded concerning this donation document for eternity. It is I, Talistene (i.e. Kalistene), the daughter of (space left blank for the father's name to be added), who was mentioned above, I am willing and I am convinced without any guile, fear, force, deceit, or deception, while there is no pressure on us, but through our very own decision, I declare that I donated my beloved son Merkoure to this holy monastery of saint Apa Phoibammon on the mountain of Jeme, so that he be a servant for it, for its sweeping and its sprinkling and for any necessary thing for those of the holy monastery, and so that this holy monastery be his master eternally, and (master over) the work of his hands and the wages of his body, whether he be in the monastery or outside of the monastery, in accordance with the demand of this superior (proestos, i.e. Sourous).

It is not possible for me or for anyone of my family members, nor for anyone at all from the people of my village, neither old nor young, neither those who rule (now), nor those who will rule over us, to be able to come and to take action against this holy monastery with respect to this particular young son, nor to file any complaint against it before a power or an authority, small or great, to do this. First, he shall not gain anything, but God will place him at his holy oratory together with me, and I will litigate with him, and he will testify on the tribunal of God to that which he has done, that he has attempted to destroy this oath and offering, this one which I have made to God, and he shall attract the great curses of the scripture, the ones in the Deuteronomion of Moses, and he shall see the kingdom of God open, but shall be prevented from entering it.

Thus, for your security, I have produced this donation document and I agree to it according to what is written in it.

I, Magarre, resident of Sne, I bear witness and I agree.

I, Papnoute, resident of Hermonthis, I bear witness and I agree to this donation document and I bear witness.

3. Child donation document of Tachel, daughter of Sophia, acting with her sister Elisabeth. She donates her son Athanasios after he received healing through the saint for a second time. The first time around, she had ignored her vow to donate her son in return for the 
saint's intercession; date: 29 August 766 (P.KRU 86).

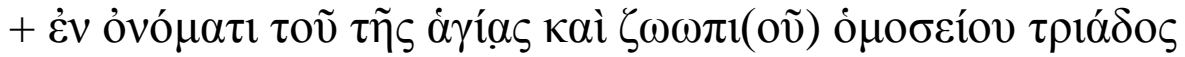

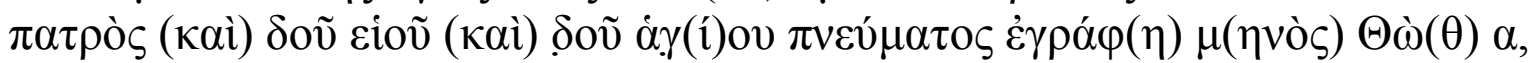
iv $\delta(1 \kappa \tau i ́ \omega v o \varsigma) \varepsilon$

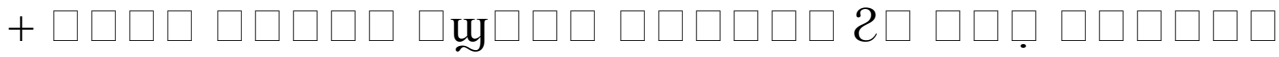

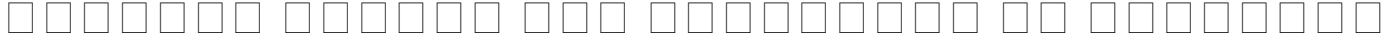

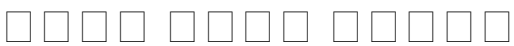

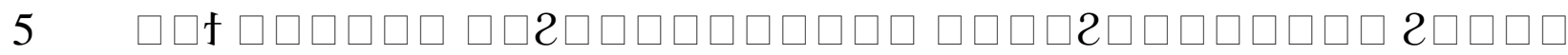

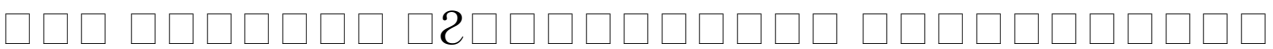

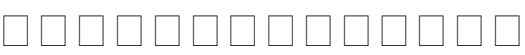

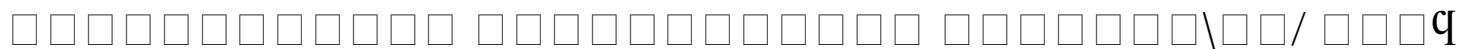

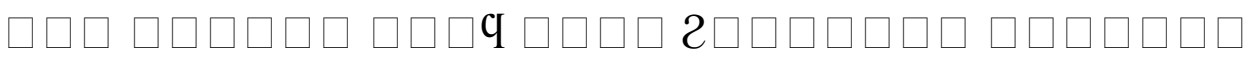

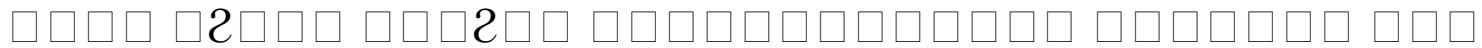

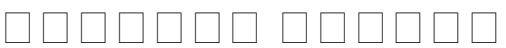

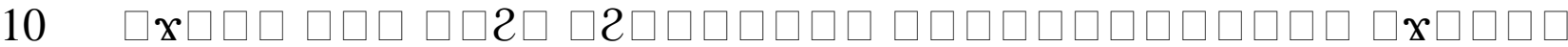
$\square \square \square \square \square \square \square \square \square \square$

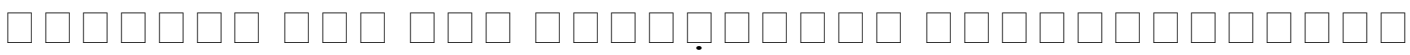

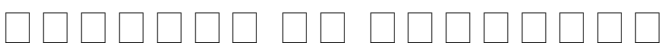

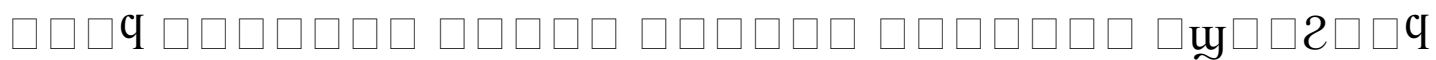

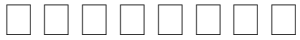

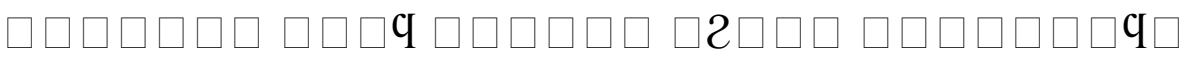

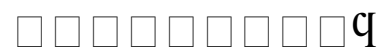

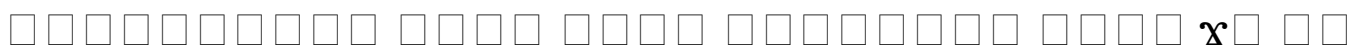
$\square \square \square \square \square$
15

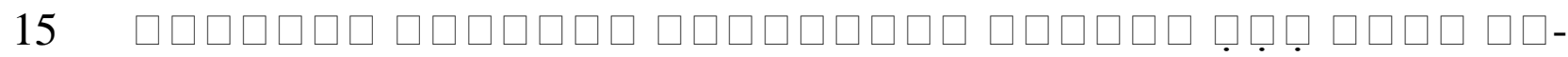

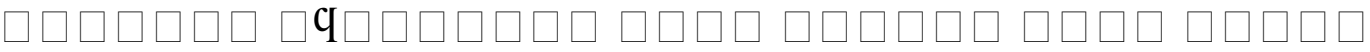

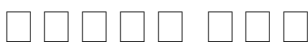

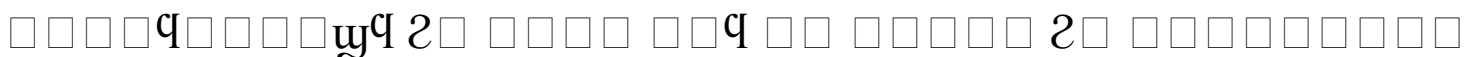
$\square \square \square \square \square \square \square 2 \square \square \mathrm{q}$

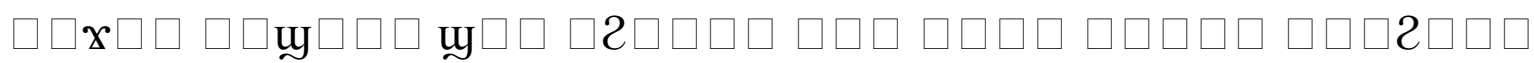
$\square \square \square \square \square-$

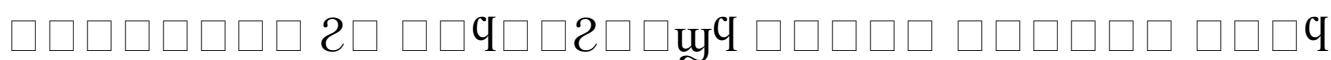
$\square \boldsymbol{\sigma} \square \square \square \square \square$

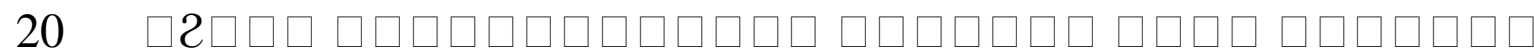

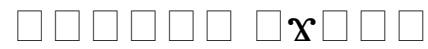

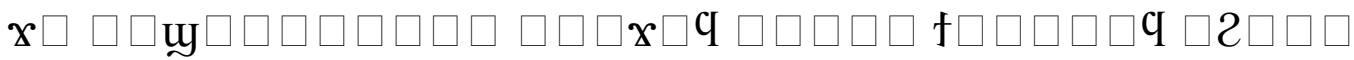

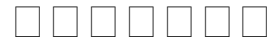

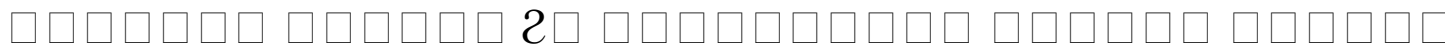
$\square \mathrm{u} \square \square \square \square \mathrm{q} \square \square$

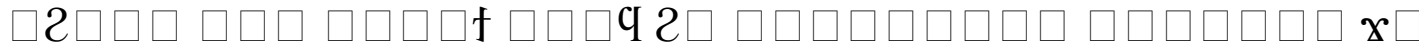




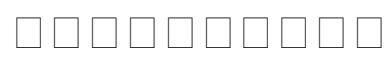

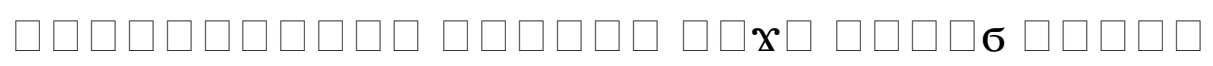

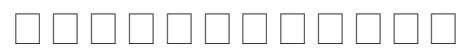

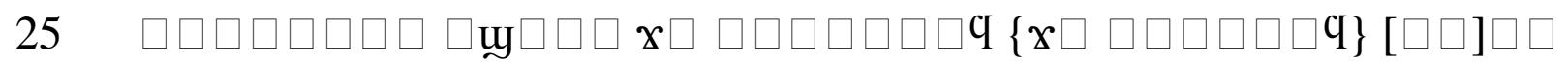

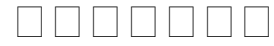

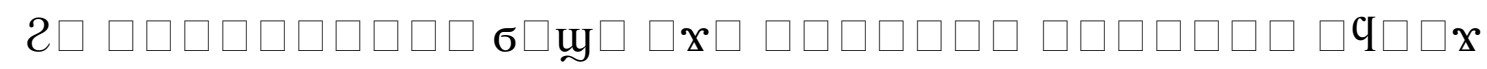

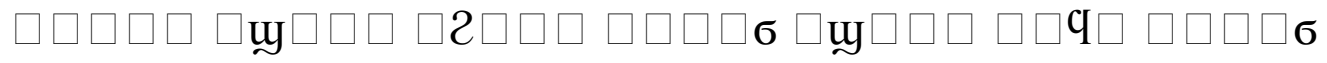
$\square \square \square \square \square \square \mathrm{w} 2 \square$

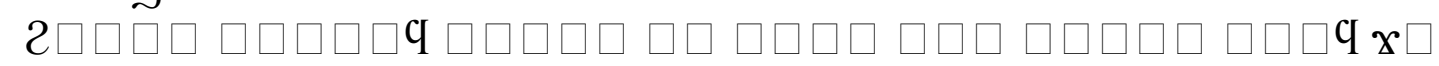
$\square \mathrm{q} \square \square \square 2 \square$

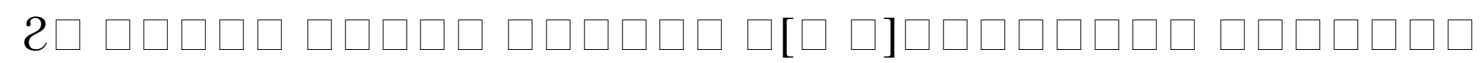
$\square \square \square \square \square 2 \square$

$30 \quad \begin{gathered}0 \\ 30\end{gathered}$ $\square \square \mathrm{u} \square \square \square \square-$

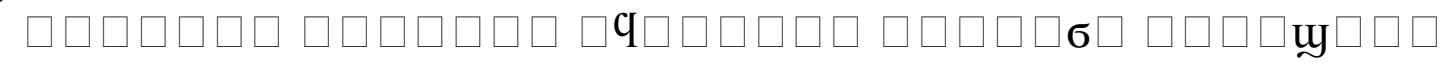
$\underline{\mathrm{y}} \square \square$

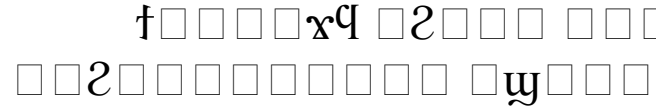

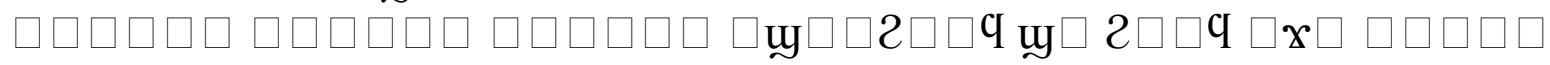

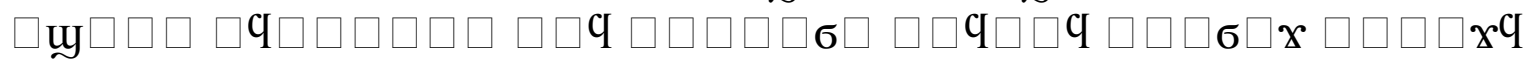

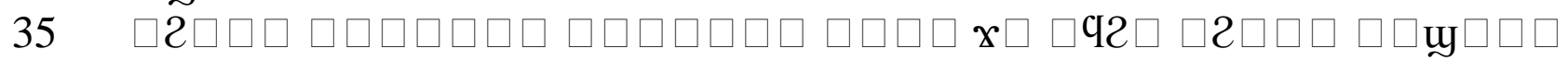

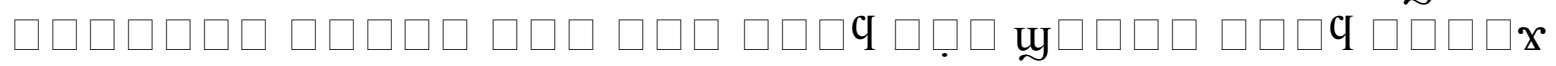
$\square \square \square$

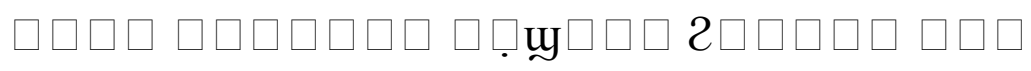

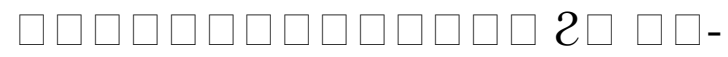

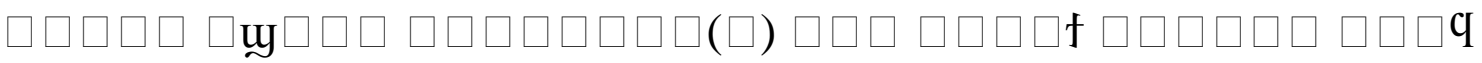
$\square \square \square \square 2$

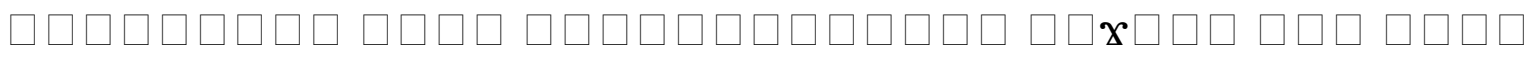
$\square \underline{\mathrm{y}} \square \square \square$

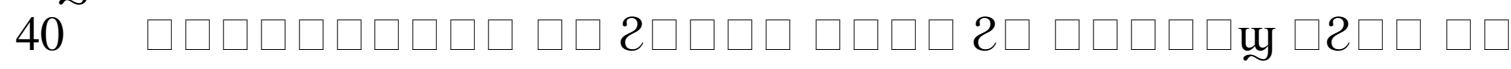
$\square \square \square \square \square-$

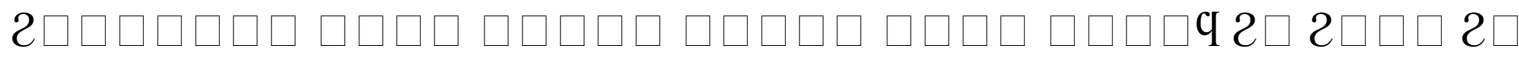
$\boldsymbol{x} \square \square \boldsymbol{\sigma}^{-}$

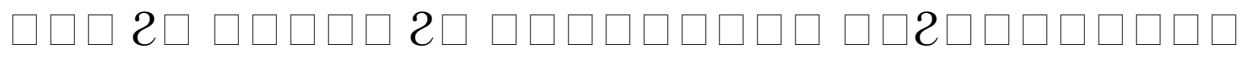

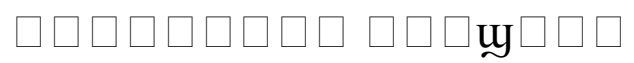

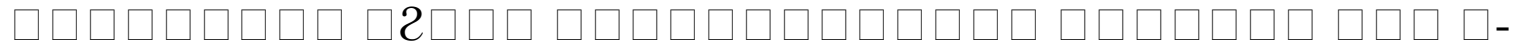

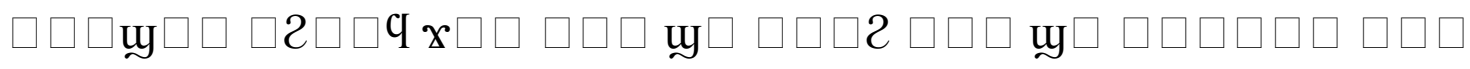

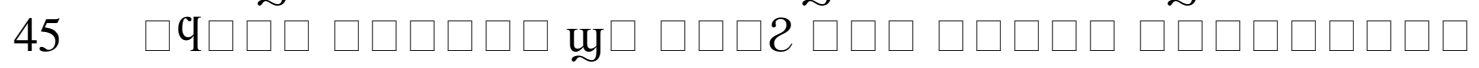

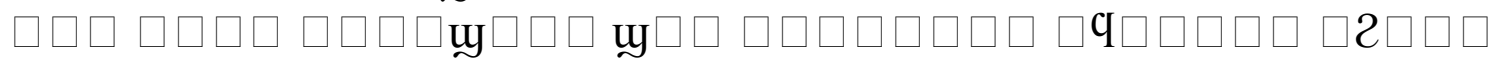

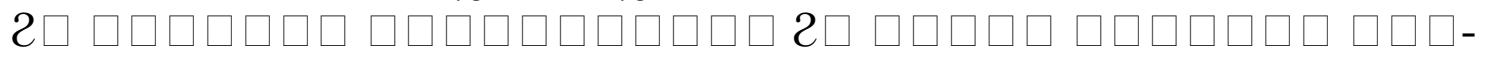

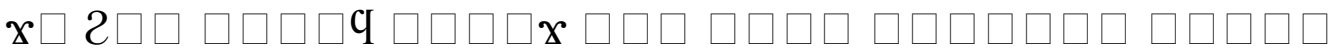




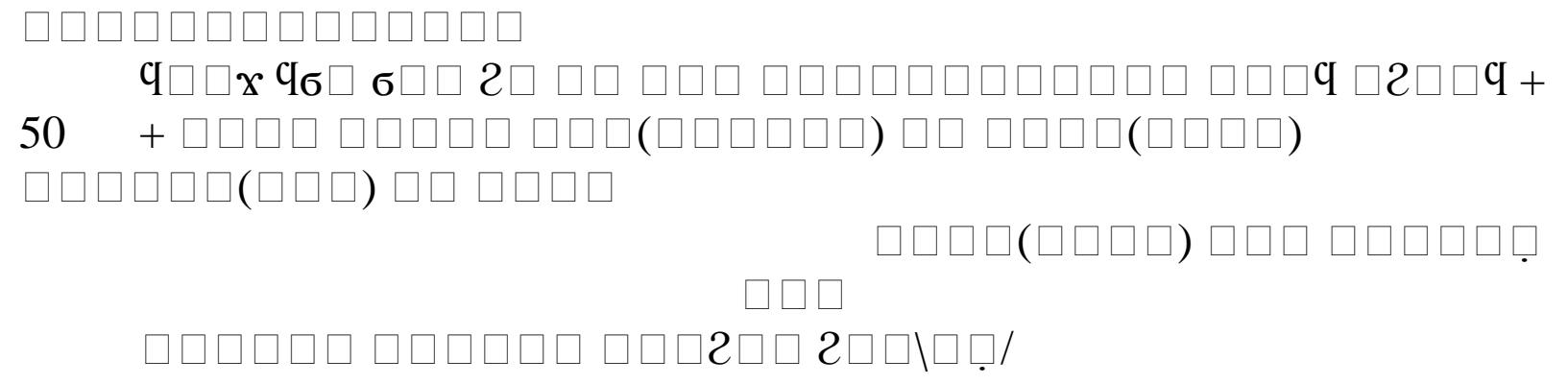

In the name of the Holy, life-giving, and consubstantial Trinity, the Father, the Son, and the Holy Spirit. Written in the month of Thoth, on the first, of the fifth indiction year.

I, Tachel, the daughter of Sophia, from Ape in the district of the city of Hermonthis, and also my sister Elizabeth partaking in this together with me, we are providing, hereafter, a scribal assistant who will sign for us and we are asking trustworthy witnesses to let them bear witness to this inviolable and, through the existing laws, unchangeable donation document.

I write to the holy monastery of Apa Phoibammon on the mountain of Jeme, this one which is yielding to the superiority of the most glorious fatherly ruling lord, master (kyrios) Psmo, the administrator (dioiketes) of the holy monastery and the entire castron (= Jeme), greetings.

Since the laws of God, the compassionate, encourage the entire human race towards an accomplishment of the good, so that the forgiveness of their sins is obtained, since there is no sinless one, except for God, this sinless one. Moreover, there is no authority, who will rule at any time, hindering anyone to do what he wants with that which is his own.

At this time in which we are now, a small male child was born to me, Tachel, the wife and married woman. In his seventh month, I pledge him as a servant to the holy monastery of Apa Phoibammon on the mountain of Jeme, in the following manner: "If God saves him from death, I shall donate him to the holy place (topos)." Afterwards, when God let the small boy grow up and he developed, this one who I have named Athanasios at the holy baptism, my confused reasoning led me into great sin, deciding with respect to the young boy, that I shall not donate him to the holy place.

When God looked onto the lawlessness I had committed, he cast the young boy into a severe illness, which lasted a long time, so that I, and anyone who saw him, assumed that he died. When I remembered the sin and audacity I had committed, I turned around again and I entreated the saint in his place (topos) in the following manner: "If you entreat God and he grants healing to this small child, I shall place him in the topos eternally in accordance with my first agreement."

Now, the merciful God, the compassionate, took pity on the young boy and granted him healing. I had carried him in my arms and had placed him in the holy place (topos), because he had fallen into a demonic illness. Everyone saw him and marveled at him.

With respect then to the security for the holy place, this donation document was asked 
from me concerning my beloved son Athanasios, this document with which I have proceeded, while being alive, my mind with me, my reasoning strong, without any physical impairment on me, but through my inner desire and my very own decision, without any guile, fear, force, deceit or deception, I acknowledge and assign my son Athansios to the aforementioned holy monastery, from now on until eternity and for any time coming after me until eternity.

The person who shall dare to come forth against this mentioned young child, will submit to the condemnation of my sacrifice at God's tribune (bema) and I will litigate with him.

As security then for the holy place, I have produced this donation document, it being firm and valid at any place at which it will be shown.

I, the deacon Papas, and Georgios, son of Philotheos, and Chael, son of John, these men, residents of Ape, we bear witness.

I, Senaga, have written for them.

Gesa Schenke (University of Oxford) 